\title{
Scale morphology and specialized dorsal scales of a new teleosteomorph fish from the Aptian of West Gondwana
}

\author{
P. G. Giordano ${ }^{1}$, G. Arratia ${ }^{2}$, and H.-P. Schultze ${ }^{2}$ \\ ${ }^{1}$ Universidad Nacional de San Luis, Chacabuco 917, San Luis, CP: 5700, Argentina \\ ${ }^{2}$ Biodiversity Institute, University of Kansas, 1345 Jayhawk Blvd., Lawrence, Kansas, 66045, USA \\ Correspondence to: P. G. Giordano (guillerminagiordano@gmail.com)
}

Received: 11 November 2015 - Revised: 12 January 2016 - Accepted: 13 January 2016 - Published: 20 January 2016

\begin{abstract}
Scales of a new species of Teleosteomorpha from the continental Aptian of the south of South America are studied. These neopterygians are from the La Cantera Formation in central Argentina, and were previously identified as Pholidophoriformes. They present ganoid scales; most of them are rhombic with well-developed peg-and-socket articulations and possessing a smooth surface. They have a straight posterior margin, but occasionally, some scales of the flank have a sinuous posterior margin with one or two serrations. The shape of the scales varies along the body from large, rectangular and deeper than long scales behind the head to the preanal region to smaller and rhomboidal scales in the caudal region. There are a few horizontal rows along the flank and about 32 lateral line scales. Thick, round ganoid scales are present in the prepelvic region close to the ventral margin. The round and rhombic scales present growth lines, which form concentric ridges on the external side. A characteristic row of deep scales forms the dorsal margin on each side of the body; a row of median ridge scales is not present. This is a unique feature of the studied fishes. Scutes covered with unornamented ganoine precede the pelvic, dorsal, and anal fins, as well as the dorsal and ventral margins of the caudal fin. The posterior margin of the dorsal lobe of the caudal fin is formed by a single line of scales, which continues and covers the base of the first principal caudal ray. Histological studies reveal a lepisosteoid-scale type with multiple ganoine layers, lack of dentine, and the presence of canaliculi of Williamson. The macro- and micromorphology of the scales shows features that are found in other teleosteomorphs, but also in other neopterygians.
\end{abstract}

\section{Introduction}

Cretaceous continental actinopterygian faunas from southern South America are scarce compared to marine ones. Records from the Southern Hemisphere have been less studied than those of the Northern Hemisphere (Arratia and Cione, 1996; Arratia, 2004; López-Arbarello, 2004). The La Cantera Formation represents upper Aptian continental deposits from western central Argentina. Among its biodiversity is a group of ganoid neopterygians (López-Arbarello et al., 2002; Arcucci et al., 2009, 2015). After more than 30 years of collecting, fishes are the only vertebrates recorded, but they have never been studied in detail (Castillo-Elías, 2011; CastilloElías et al., 2012; Giordano and Arratia, 2011, 2013).

Neopterygians from La Cantera Formation have been assigned to the order Pholidophoriformes (Berg, 1937) since 1969 (Flores, 1969). However, such assignment was based on unreliable generalized characters found in many actinopterygians (Arratia, 2000, 2013), such as specimen size, the presence of bones covered by ganoine, and ganoid scales. These were the common traits for identifying "pholidophoriforms", a group now interpreted as non-monophyletic (Arratia, 2000, 2013). Our current studies suggest that the fishes from the La Cantera Formation are not "pholidophoriforms". Their cranial and postcranial features represent a new combination of characters that indicates new species of neopterygians. At least two of the species from the La Cantera Formation are within the Teleosteomorpha (Giordano, 2015), and one of them is the subject of study here.

Scales of fishes can provide valid taxonomic and phylogenetic information for different taxa (e.g., Schultze, 1966, 1996, 2015; Sire and Meunier, 1994; Richter and Smith, 1995; Meunier and Brito, 2004; Vullo et al., 2009; Arra- 
tia and Schultze, 2012). Detailed descriptions (micro- and macromorphology) of these structures could be a tool for helping to clarify taxonomic assignments and possible relationships of fishes from the La Cantera Formation.

\section{Geological setting}

The material examined in this study originates from the type locality of the La Cantera Formation in western central Argentina $\left(32^{\circ} 49^{\prime}, 33^{\circ} 06^{\prime} \mathrm{S}\right.$ and $66^{\circ} 59^{\prime}, 66^{\circ} 46^{\prime} \mathrm{W}$; Fig. 1$)$. The formation outcrops in the San Luis Basin is part of the Del Gigante Group that corresponds to a continental filling of an extensive system related to the break-up of Gondwana (Rivarola and Spalletti, 2006). The La Cantera Formation has been interpreted as a lacustrine environment based on its lithological characteristics, as well as the presence of freshwater algae and ostracods. It has a measured thickness of $31 \mathrm{~m}$ at its type locality (Prámparo, 1999a) and is composed of papery, laminated green-grey mudstones interbedded with siliciclastic siltstones (Criado-Roque et al., 1981) and layers of primary gypsum. The gypsum layers go from $1 \mathrm{~mm}$ to decimeters in thickness, most of them with laminar, massive, and granular textures (G. CastilloElías, personal communication, 2013). The La Cantera Formation could represent ephemeral lakes related to a fluvial environment with some periods of a quiet lacustrine system (Criado-Roque et al., 1981), which allowed the preservation of delicate structures, such as leaves, stems, flowers, frail fish remains, and insect exuviae. The actinopterygian fishes occur within a rich paleobiological association including plant remains and palynomorphs belonging to angiosperms, gymnosperms, bryophytes (Tallithes sp., Muscites sp., among others) and pteridophytes, freshwater ostracods, and different insect groups - for example, Orthoptera, Coleoptera, Diptera, among others, and Notonecta mazzoniae, a fresh water heteropteran (Arcucci et al., 2009, 2015; López-Arbarello et al., 2002; Petruleviciius et al., 2010; Puebla, 2009; Puebla et al., 2012). The microphytoplankton is dominated by freshwater algae (Scenedesmus, Tetrastrum, ?Crucigeniella, Tetraedron, Botryococcus, Leiosphaeridia). At some levels of the section, this microphytoplankton constitutes more than $80 \%$ of the total assemblage (Prámparo, 1999b). The angiosperm palynomorphs are present at low percentages, but they become more frequent at the top of the studied sections. They are useful in determining the age of the formation. The taxa identified are Afropollis (A. operculatus, A. zonatus, and A. aff. jardinus), Retimonocolpites sp., Stellatopollis sp., Clavatipollenites sp., Tucanopollis, Pennipollis (ex. Brenneripollis) peroreticulatus, and Asteropollis complex (Stephanocolpites mastandreai/Huitrinipollenites transitorius). Afropollis and the Astereopollis complex appear in Argentina in the Aptian, indicating a Cretaceous age for the formation. Finally, the lack of tricolpate pollen in the microflora places the La Cantera Formation in the late Aptian (Prámparo, 1990, 1994, 1999a, 2012; Prámparo et al., 2007).

\section{Material and methods}

\subsection{Material}

Specimens studied in this work are small, approximately $5.5 \mathrm{~cm}$ in total length. Their body flanks are totally covered by ganoid scales, and they have a hemiheterocercal caudal fin (Fig. 2). Fishes studied herein have characters that place them within the clade Teleosteomorpha (Arratia, 2001). They share with other Teleosteomorpha the presence of a unique supramaxillary bone lying on the last dorsal third of the maxilla, two suborbital bones, a complex pectoral ray (for complex ray definition see Arratia, 2008, 88-91), two principal rays forming the dorsal and ventral margins of the caudal fin, and the main leading ray (the longest segmented-andbranched ray) corresponding to the second principal ray in the dorsal and ventral margins of the caudal fin, as well as in the dorsal and anal fins, besides other characters (Arratia, 2008, 2013; Giordano, 2015).

Detailed observations of the macro- and microstructure of the scales have been made mostly on complete or almost complete specimens, but also on disarticulated ones, as well as on isolated scales from different regions of the body (see list of samples below).

The material revised for this research is held in the following Argentinian institutions: MIC, Museo Interactivo de Ciencias in Universidad Nacional de San Luis (UNSL), San Luis; CORD, Museo de Paleontología in Universidad Nacional de Córdoba, Córdoba; and MLP, Museo de La Plata in Universidad Nacional de La Plata, Buenos Aires.

Specimens of Teleosteomorpha n. sp. 1 (after Giordano, 2015) are listed below:

Complete or almost complete specimens: MIC-V46 b; MICV52; MIC-V519 a; MIC-V523; MIC-V535 a, b; MIC-V568; MIC-V621 a, b; MIC-V635; MIC-V560; MIC-V568; MICV644; MIC-V659 a, b; MIC-V660 a, b; MIC-V661 a, b; MIC-V662; MIC-V695 a; MIC-V701 a, b; MIC-V702; MIC-V703 a, b; CORD-PZ 2027, 2029; CORD-PZ 2028, 2033; CORD-PZ 2087; CORD-PZ 2088; CORD-PZ 2092; CORD-PZ 2030; MLP 85-IV-15-1; MLP 85-IV-15-2 -4; and MLP 85-IV-15-6 -7.

Isolated scales and disarticulated-fragmented specimens (most of them not catalogued and bearing the field name): MIC-V634; MIC-V699; MIC-V700; MIC-V706 a, b; "T5.5", "T-99"; "T-123"; and "8", "C1", “C3", "P2008", and "5.5-AM".

\subsection{Methods}

The senior author mechanically prepared the material, and some specimens were also prepared for histological and 


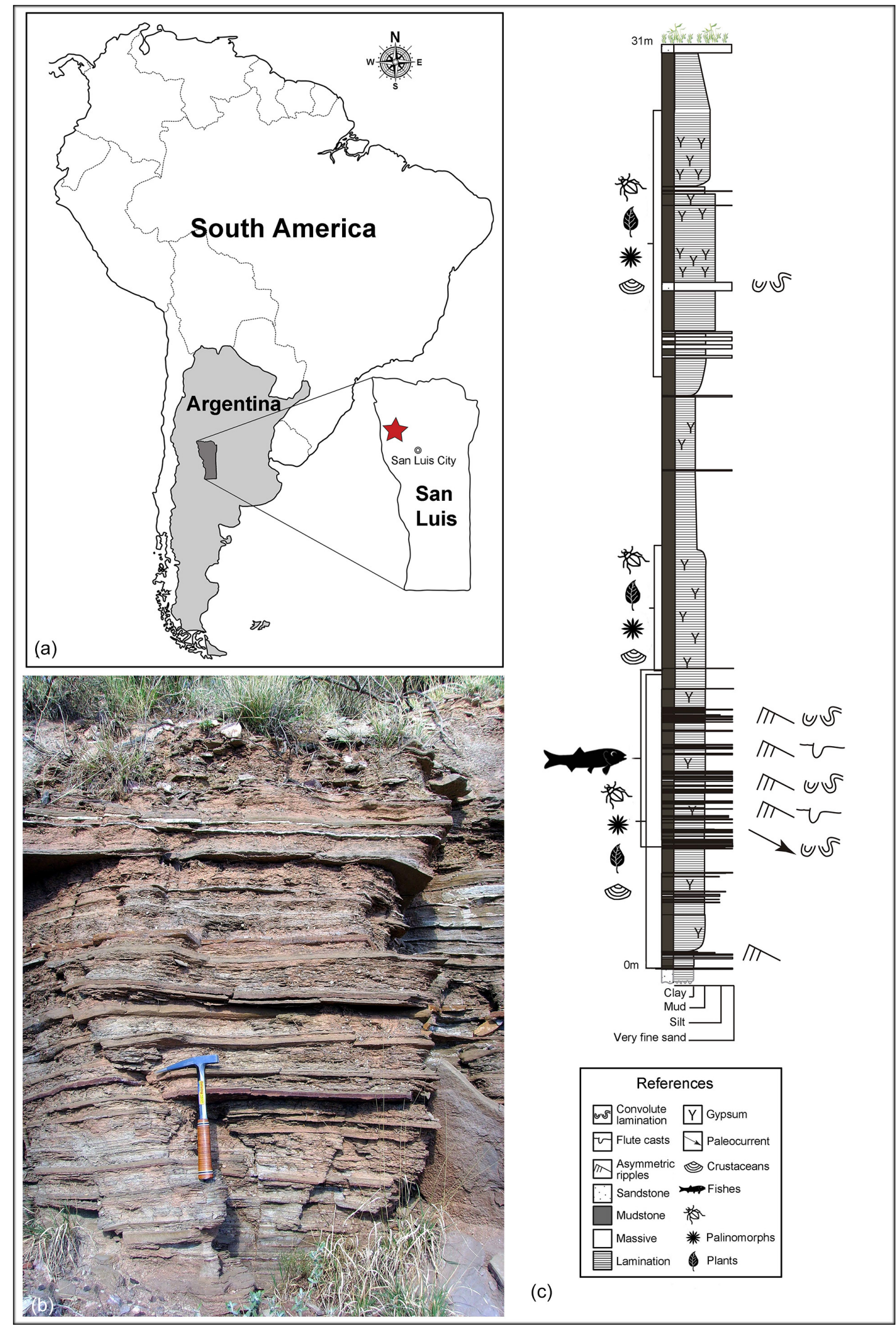

Figure 1. (a) Geographic provenance of specimens from the La Cantera Formation, San Luis, Argentina. Star indicates the type locality. (b) Stratigraphic section in the type locality. (c) Interpretative stratigraphic sequence of La Cantera Formation at the type locality. Courtesy of Gabriela Castillo-Elías. 

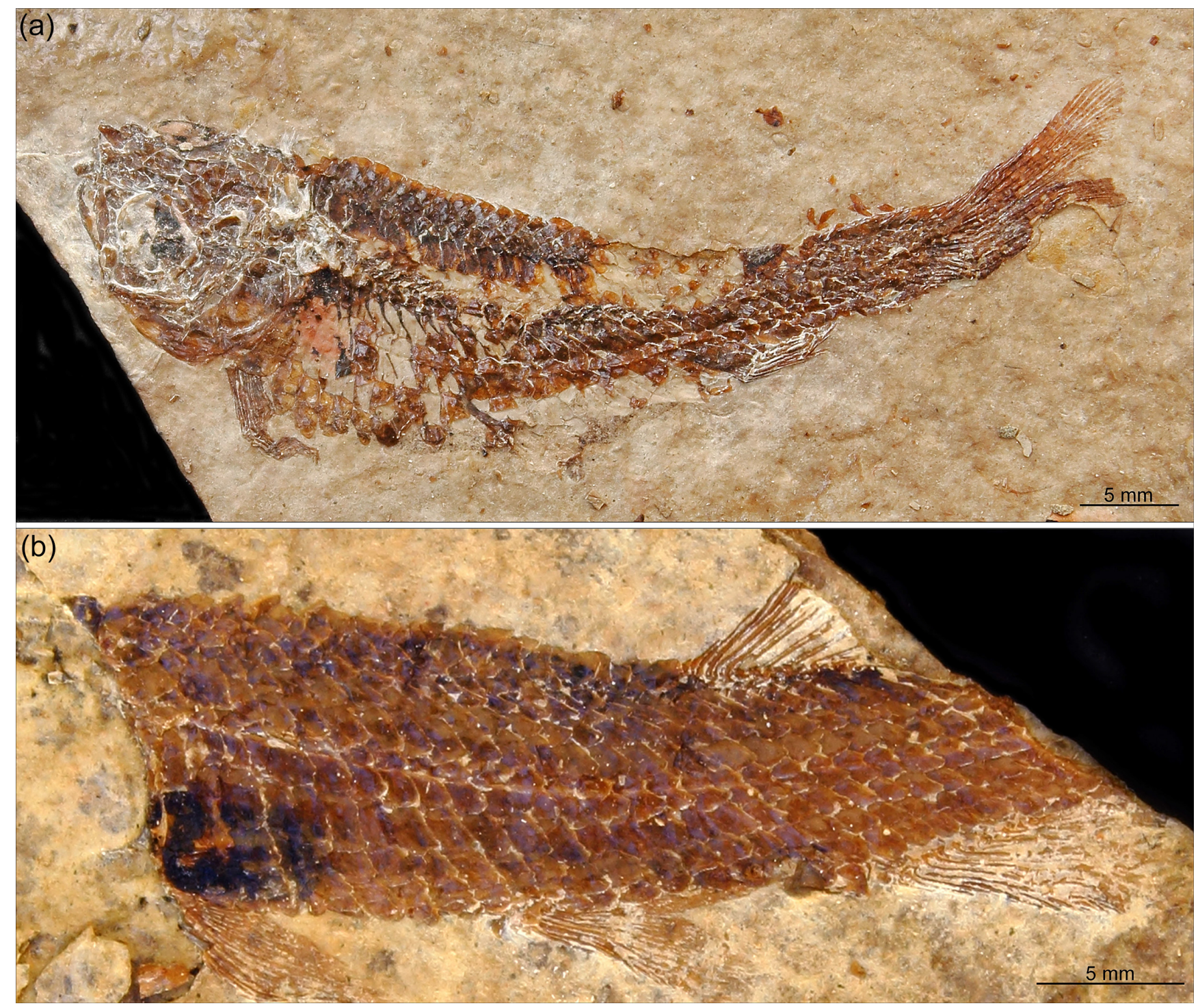

Figure 2. Teleosteomorpha n. sp. 1. (a) MIC-V701a one of the most complete specimens from the La Cantera Formation. (b) Specimen MIC-V703a, showing body completely covered by ganoid scales.

scanning electron microscopy (SEM) studies in the laboratories of the UNSL.

Specimens were studied by direct observation and interpretative drawings were made using a binocular microscope with an attached camera lucida (Leica M80) at UNSL, following Schultze $(1966,1996)$ for interpretation of scales. The surfaces of scales were observed under SEM, and histological sections were analyzed under a petrographic microscope (Leica DM750P) using regular and polarized light, following Gayet and Meunier (1986). Photographs were taken with digital cameras (Sony Cyber-shot DSC-HX1 and Canon EOS T3i).

\section{Description of scales}

\subsection{Macromorphology}

The whole body flank, including the bases of the unpaired fins, is covered by ganoid scales (Fig. 2b). Most scales have a well-developed peg-and-socket articulation (Figs. 3 and 4), except the postanal ones. The anterior margin of all scales is devoid of anterodorsal or anteroventral processes. The posterior margin of most scales is straight; nevertheless, some flank scales have one serration (Fig. 3a-c). The ventral border is sinuous (Fig. $3 \mathrm{~b}$ and c). The inner surface of each scale bears the typical keel of ganoid scales that serves as attachment for Sharpey's fibers, which connect with the keel of adjacent scales in the next vertical row (Figs. 3c and 5a). 


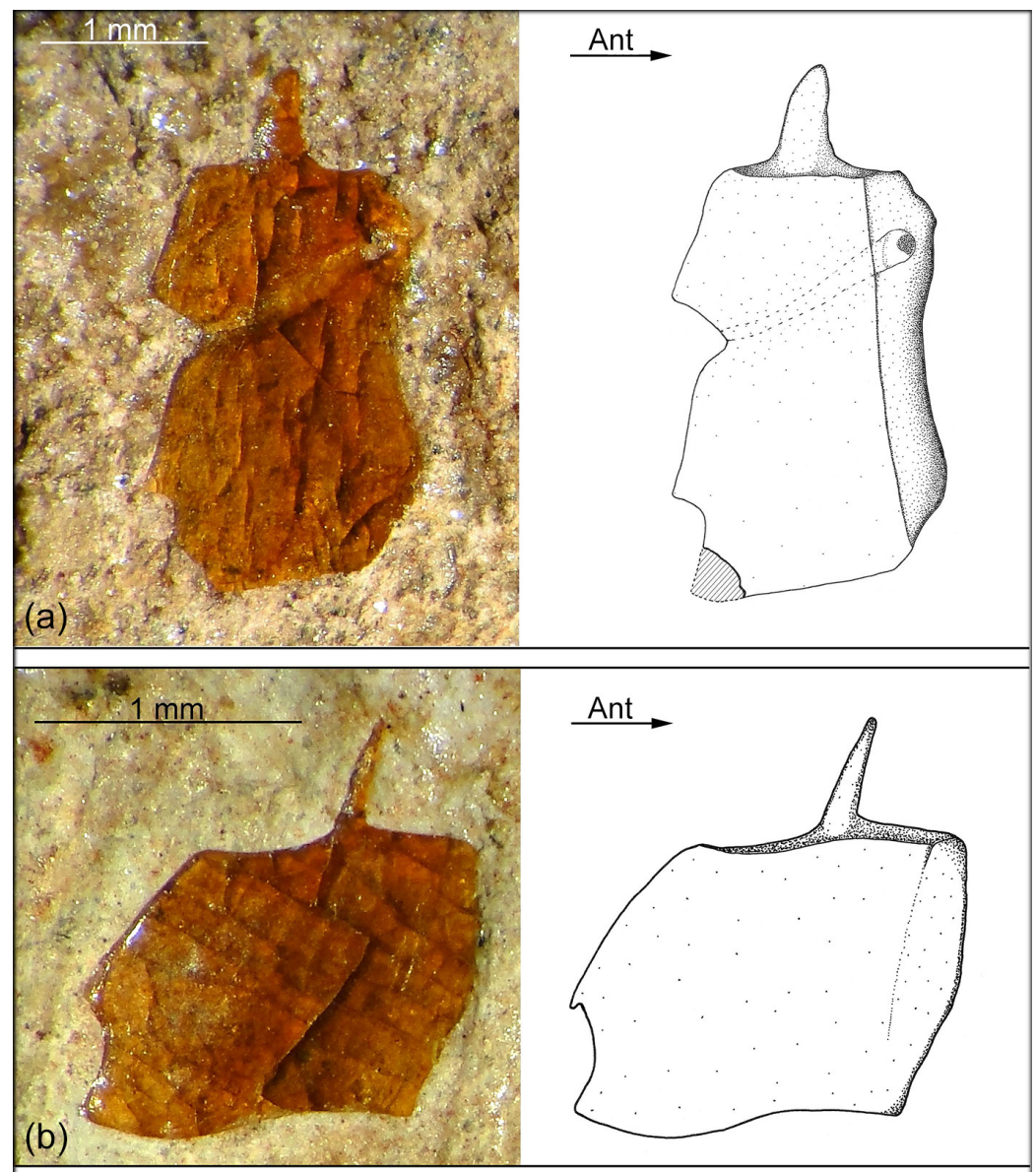

(b)
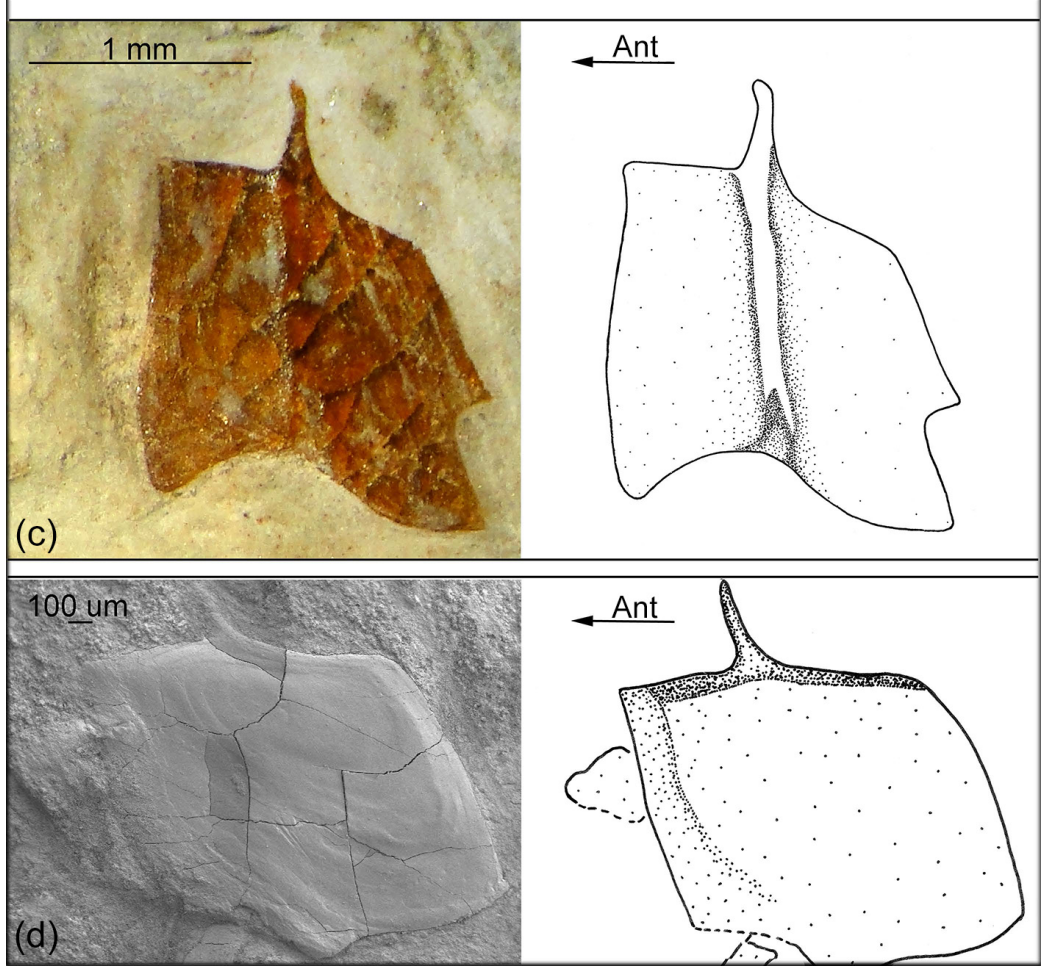

Figure 3. Sample of pre-anal ganoid scales with well-developed peg-and-socket articulation of Teleosteomorpha n. sp. 1. (a) MIC-V634, an isolated mid-flank scale, which carries the lateral line. (b) A ventral flank scale of specimen MIC-V631, showing a serrated posteroventral margin. (c) Specimen MIC-V706b, inner surface of another ventral flank scale, with serrated posteroventral margin and the typical keel and groove for peg-and-socket articulation. (d) SEM photograph $(\times 50)$ of specimen MIC-V706a; ant, anteriad. 

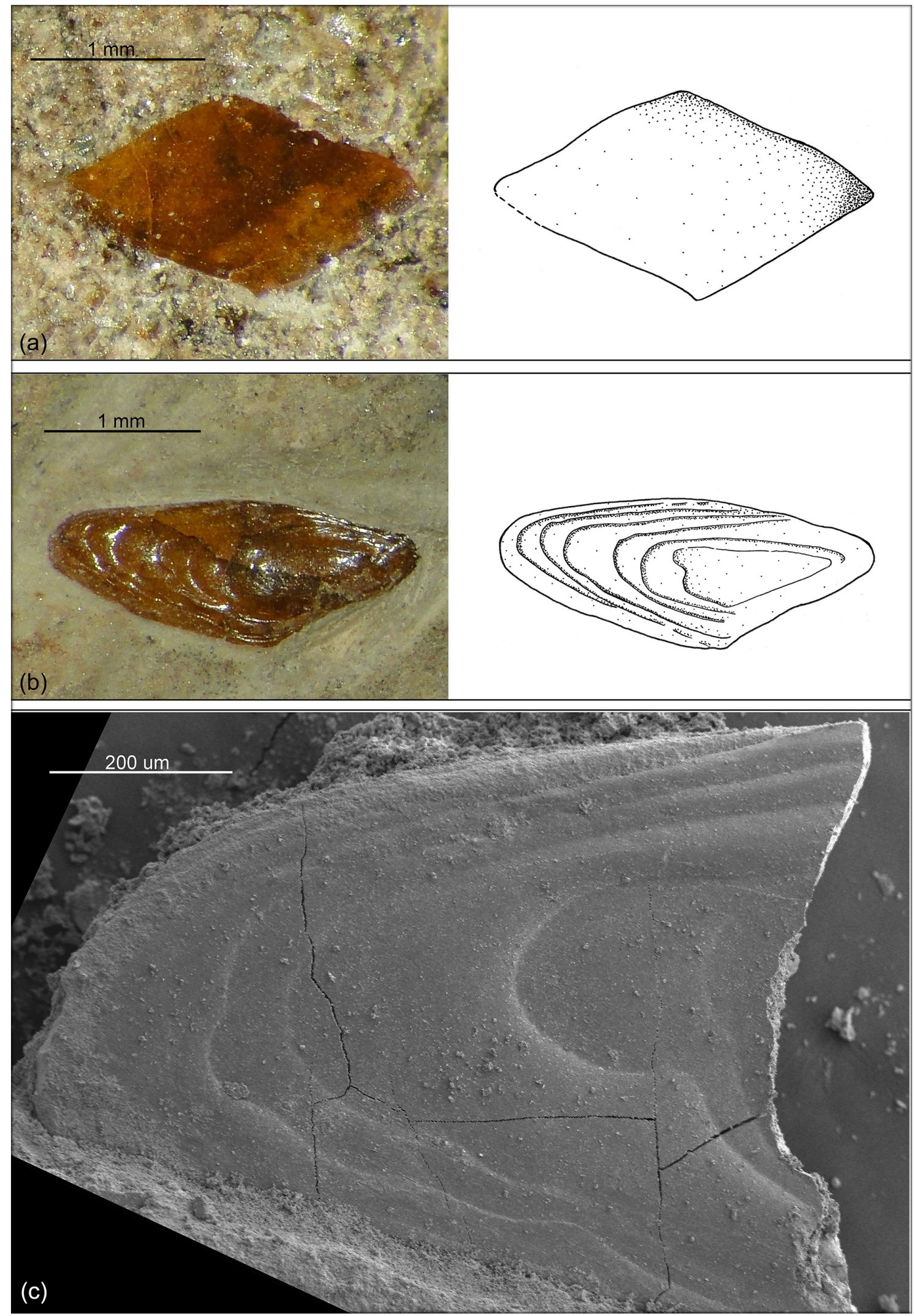

Figure 4. Post-anal rhombic scales of Teleosteomorpha n. sp. 1. from the La Cantera Formation. (a) MIC-V699, an isolated scale. (b) Sample MIC-V706b, showing concentric pattern of growth lines in external view. (c) Other sample of MIC-V706b under SEM; growth lines on external surface. 

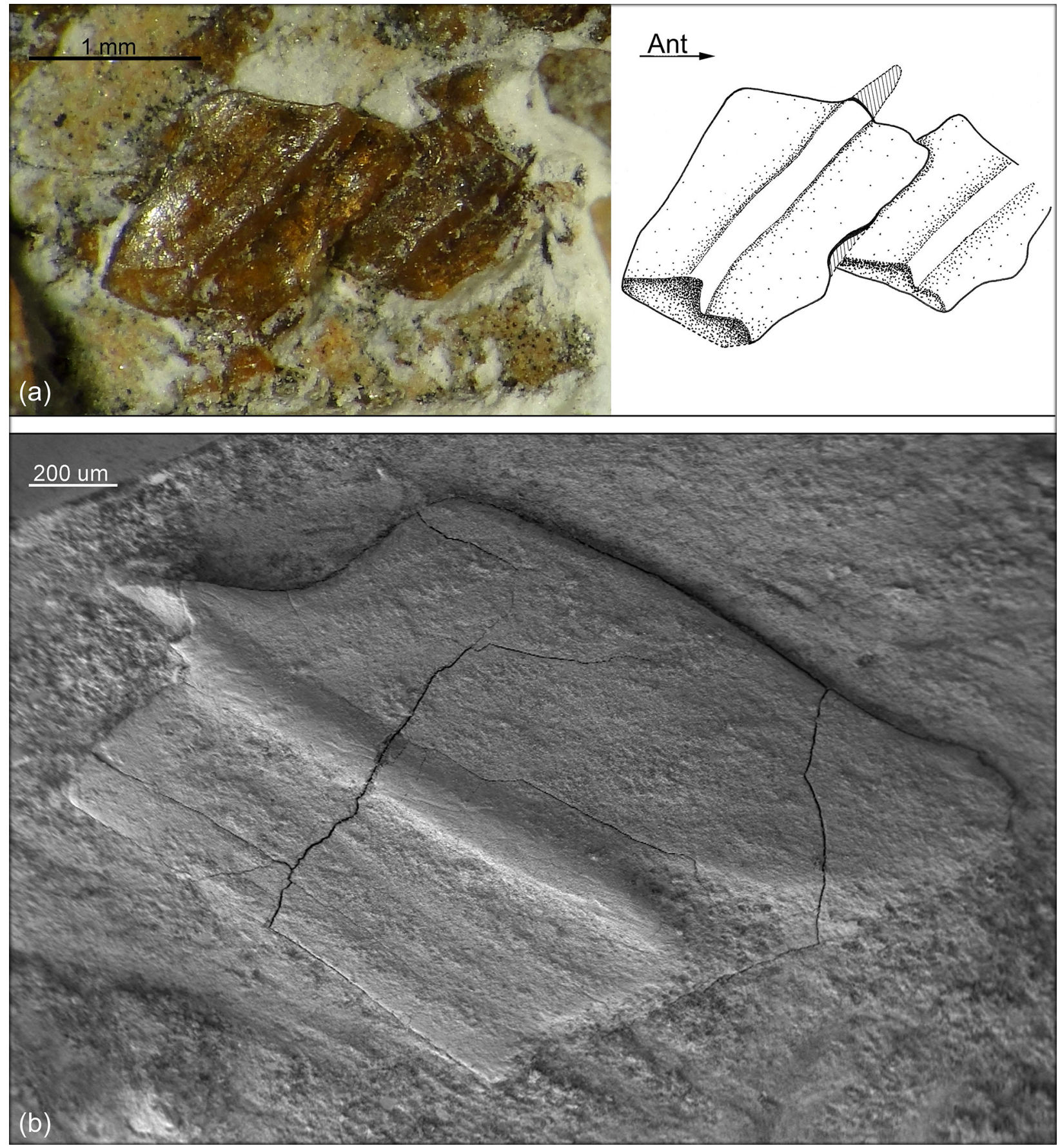

Figure 5. Inner view of middle flank scales of Teleosteomorpha n. sp. 1, showing main elements of peg-and-socket articulation, the keel, the groove, and the peg. (a) Picture and camera lucida drawing of some scales of specimen MIC-V523. (b) SEM photograph of one of the scales of sample MIC-V706a; ant, anteriad.

Most scales, as well as the surfaces of head bones, have a smooth ganoine surface. The scales of the most ventral scale row present a subtle concentric pattern of growth lines in the prepelvic margin (Fig. 6). The same concentric pattern can be seen in a few caudal scales (Fig. $4 \mathrm{~b}$ and c). At the level of the dorsal fin, scales are arranged in five to seven (in exceptional cases eight) horizontal rows along the flank, demarcating a shallow body, which is about $23 \%$ of standard length.

Shapes and sizes of the scales vary according to body regions. The scales are rectangular and deeper than long between the head and pre-anal region, and they become smaller and rhomboidal with no peg caudally, conferring more flex- 


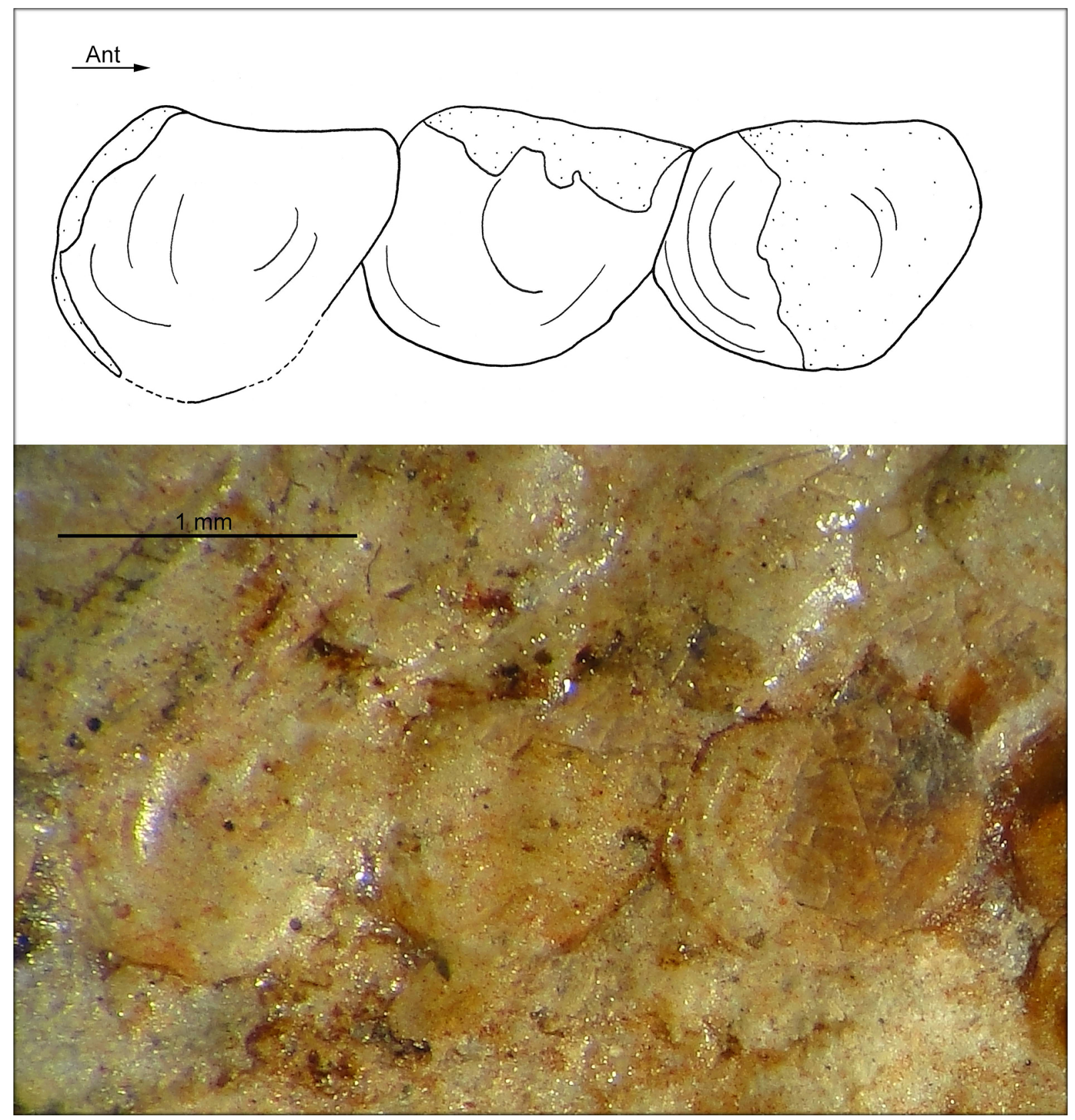

Figure 6. Teleosteomorpha n. sp. 1. Rounded ventral pre-anal scales in specimen MIC-V621b. Note the growth lines; ant, anteriad.

ibility to this region (Fig. 7). The scales of each horizontal scale row, especially those in the pre-anal region, are different in shape.

The most dorsal scale row consists of a series of deep scales devoid of spines or processes. Such a scale row forms the dorsal margin of the body on each side (Figs. 8 and 9). These scales are peculiar, forming the dorsal margin in pairs; there is a row on the left side and another on the right side at the dorsal margin (Figs. 9 and 10). This pattern begins behind the skull in some specimens (Figs. 9 and 10), but it starts in about the 10th vertical scale row in others (Fig. 8a). In spec- imen MIC-V701, the dorsal scales have a caudad-directed point in the opposite direction to the rest of the flank scales (Figs. 2a and 10).

The second to fourth horizontal scale rows (from dorsal to ventral) carry the lateral line so that the lateral line has a middle to dorsal position on the flank. There are some exceptions where the lateral line is placed in the fifth horizontal scale row. The lateral line extends over 32 or 33 scales along the body. The lateral line scales change their shape and size, depending on the regions of the flank, as in the other scales of the body. Changes in the scales along the lateral line are grad- 


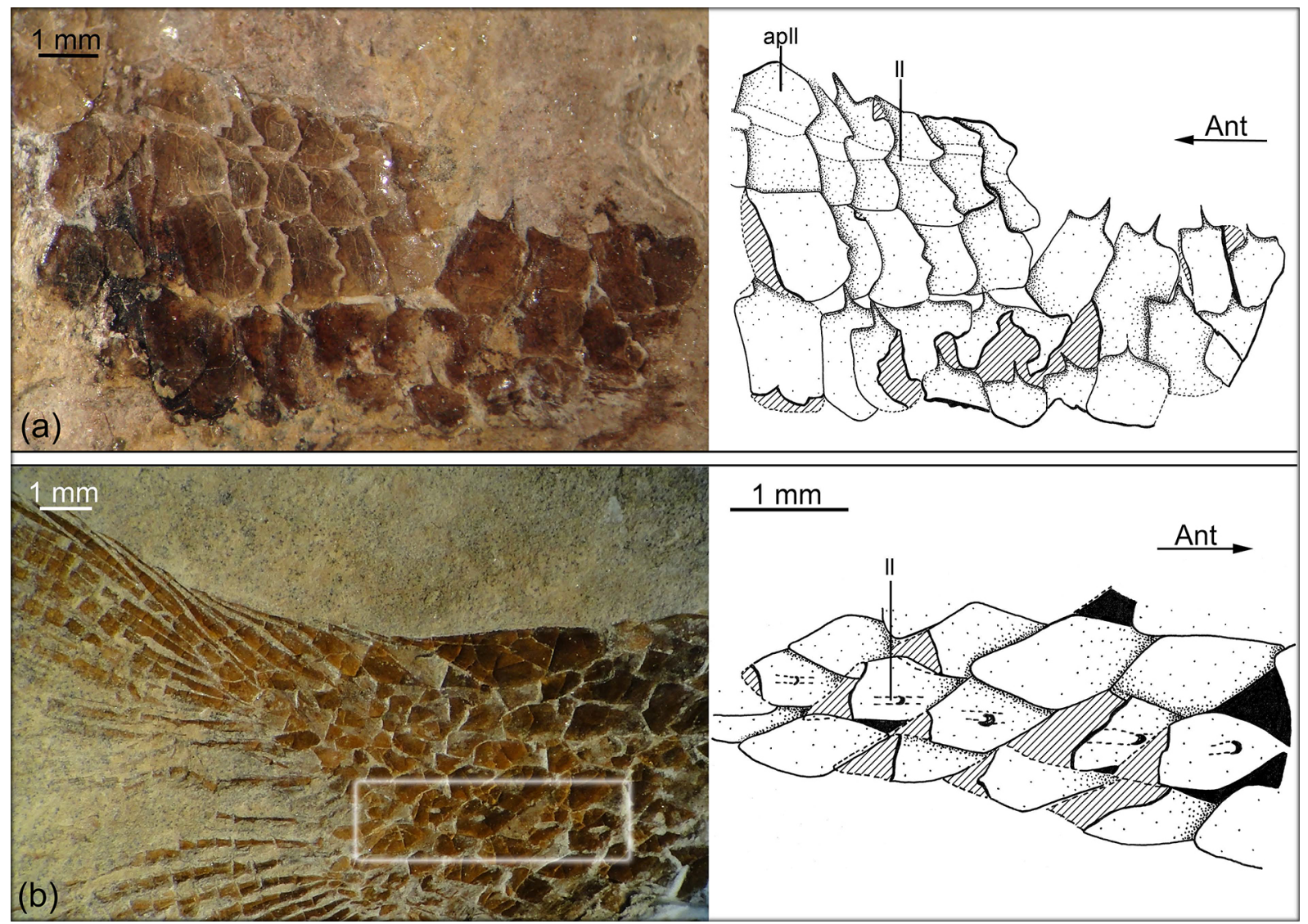

Figure 7. Squamation of the flank of Teleosteomorpha n. sp. 1 from the La Cantera Formation. (a) Pre-anal scale patch in MIC-V635. (b) Scales from caudal peduncle of MIC-V523. Note that the lateral line passes through them; asll, additional pore of lateral line or pitline; 11, main lateral line; ant, anteriad.

ual, but it is possible to differentiate between four morphologies: (1) the lateral line scales of the pre-pelvic region are deeper than long and present a notch on their posterior margin (Figs. 3a and 7a). (2) The scales decrease in depth in the pelvic fin region, becoming almost square, and are marked by a small notch at their posterior margin. (3) Lateral line scales above the anal fin are square (Fig. 11). (4) The lateral line scales of the caudal peduncle are rhombic, and in some cases have, in addition to the posterior opening, a pore in a nearly central position (Fig. 7b).

The lateral line ends in the last scale of the basal axial lobe of the caudal fin with the inversion of the scale rows (Fig. 12). No accessory lateral line has been observed in any specimen; however, there are some scales with additional pores in branches of the lateral line canal (Fig. 11b).

Vertical scale rows above the lateral line have the same pattern as vertical rows below it, so there is no intercalation of scale rows into the dorsal vertical rows. Three or four horizontal scales rows are arranged below the lateral line. Those of the pre-anal region are deeper than long, except the scales of the most ventral horizontal row, which are rounded to square and show concentric growth pattern (Fig. 6). All ven- tral scales become rhomboidal in the caudal region (Figs. 4 and 7).

In the upper lobe of the caudal fin, there are four or five scale rows with reversed direction to that of the body (Fig. 12). The most posterior scale row forms the posterior margin of the dorsal lobe with three to five scales that start just above the last lateral line scale. The row continues with a line of two to five scales that cover the base of the first principal caudal ray (Fig. 12). Both dorsal and ventral margins of the caudal fin are preceded by elongate, oval scutes. The dorsal scute is slightly broader than the ventral one; nevertheless, both scutes are almost of the same size (Figs. 12 and 13a-b). Also, large, slightly oval or round scutes precede the pelvic, dorsal, and anal fins. All mentioned scutes are covered by unornamented ganoine. Specimen MIC-V519a shows three anal scutes of different shapes and size just in front of the anal fin (Fig. 13c).

\subsection{Micromorphology and histology}

SEM studies reveal that even though flank scales seem to have a smooth surface, at a magnification of $3000 \times$, they 
70 P. G. Giordano et al.: Scale morphology and specialized dorsal scales of a new teleosteomorph fish from the Aptian

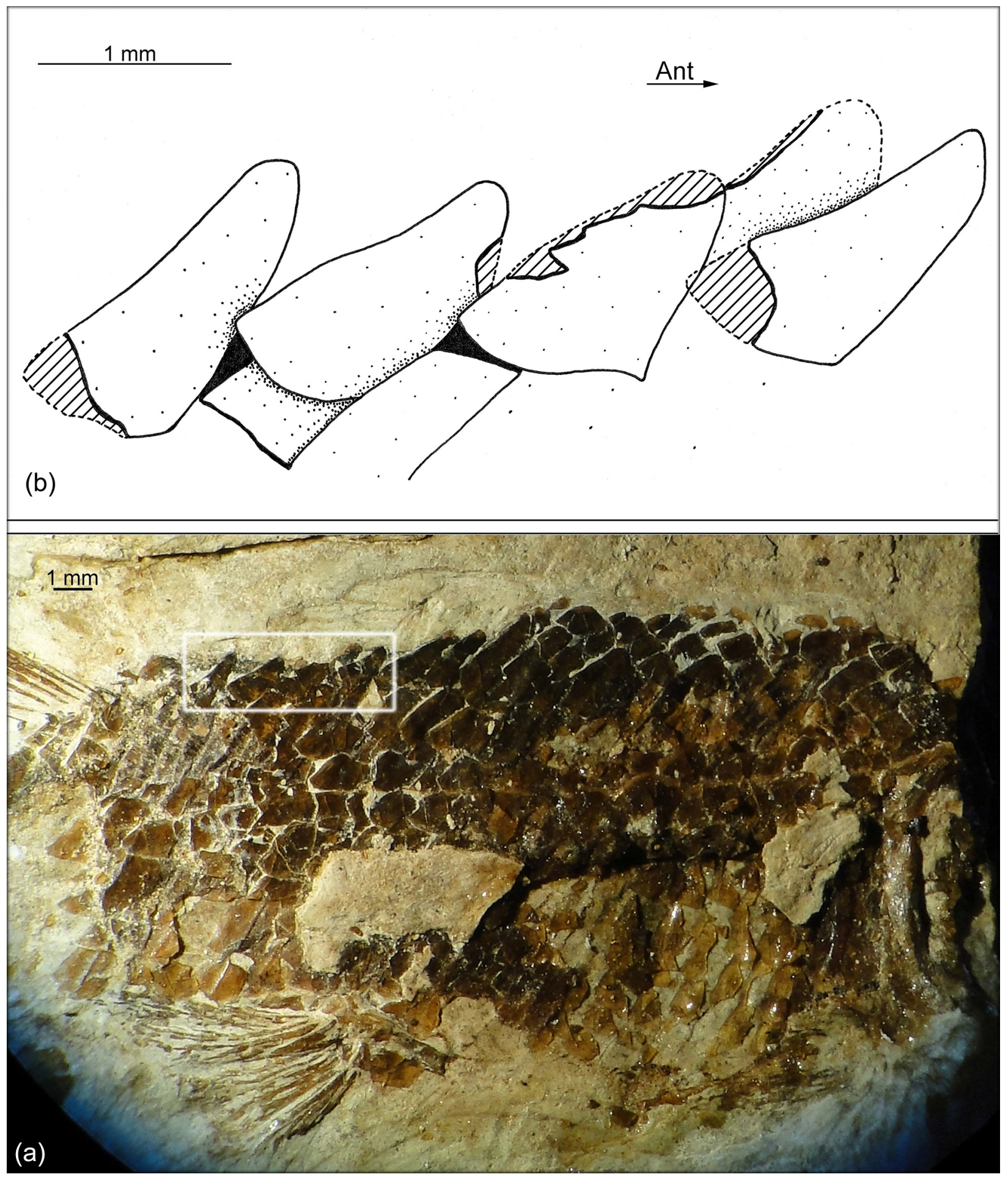

Figure 8. (a) Flank of Teleosteomorpha n. sp. 1 (MIC-V662). (b) Detail of the uppermost dorsal scale row in the pre-anal region; ant, anteriad.

actually present striae (Fig. 14). The striae cover the surface of the scales and are arranged in an anterodorsal-toposteroventral pattern. We cannot decide whether these striae are original structures of the surface or scratches caused af- ter death of the fish. Microtubercles described for the surface of ganoine by Schultze (1966), Ørvig (1967), and Gayet and Meunier (1986) are not present. 

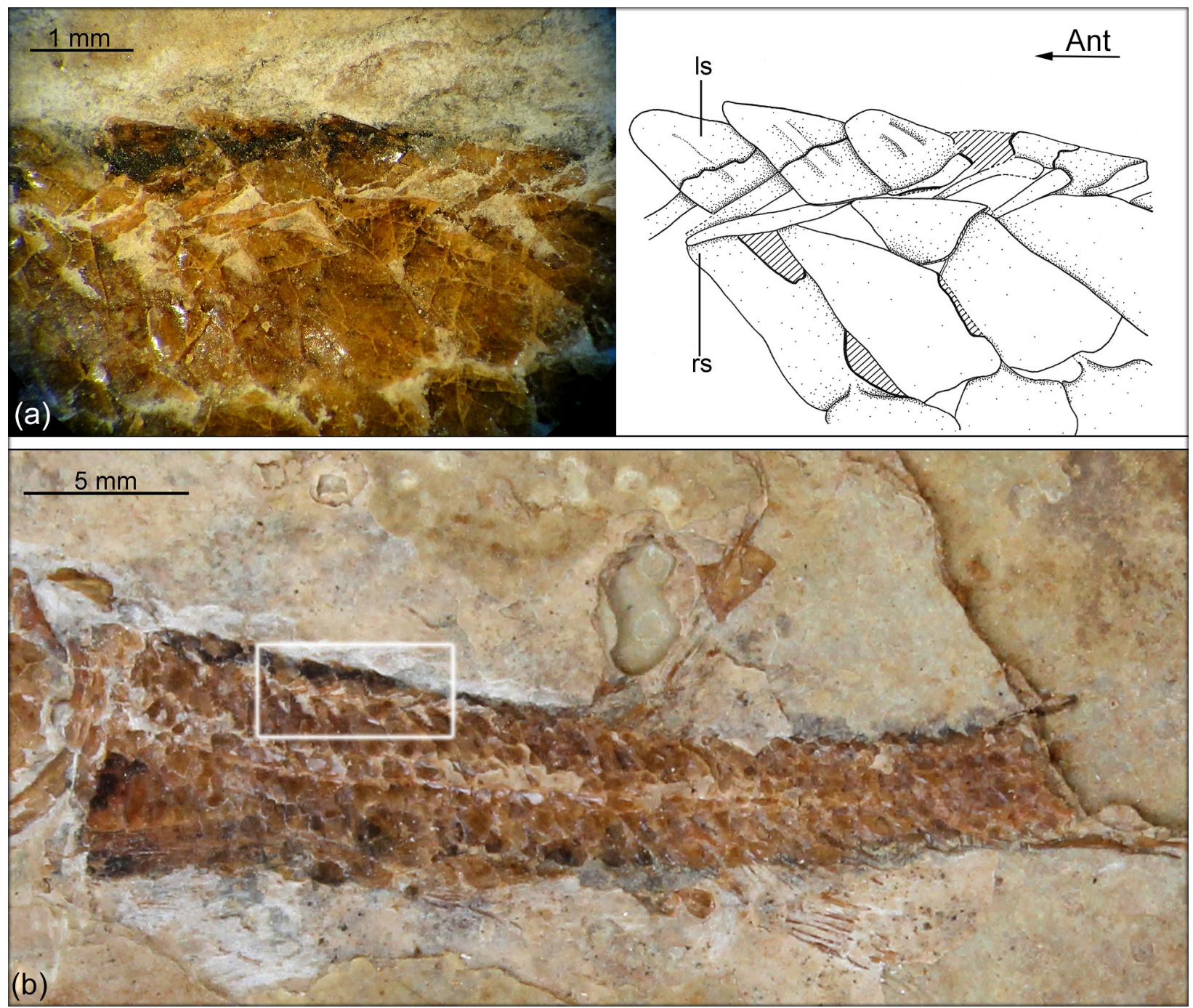

Figure 9. (a) Postcranial region of Teleosteomorpha n. sp. 1 (MIC-V660); white rectangle marks detail in (b). (b) Picture and camera lucida drawing showing the particular pattern of missing median dorsal row, but a series of scales on each side of dorsal margin; ant, anteriad; ls, left side scales; rs, right side scales.

Histological slides show a lepisosteoid-type scale where ganoine layers directly overlie the surface of the basal bony plate, and dentine is lacking between both tissues (Fig. 15a). Ganoine, as in most actinopterygians, is composed of multiple layers (Sire et al., 2009), as can be seen in photographs under normal and polarized light (Fig. 15b and c). Besides the ganoine layers, the histological microstructure shows the basal bony plate with all the lepisosteoid features (Schultze, 1966; Fig. 15d herein): stratified lamellar bone, osteocyte spaces, canaliculi of Williamson, Sharpey's fibers, and vascular canals. Sharpey's fibers are connective fibers that attach keels horizontally in neighboring vertical scale rows. Vertically, scales are connected by peg-and-socket articulation (Schultze, 1996).

\section{Comparison with scales of other Teleosteomorpha and other Neopterygii}

The macromorphology of the scales described shows features found in other neopterygians, including most Teleosteomorpha or stem-group teleosts, with particular characters unique to Teleosteomorpha n. sp. 1.

The clade Teleosteomorpha comprises the large group of Teleostei plus their stem groups (Arratia, 2001: Fig. 3). According to Arratia's (2013) phylogenetic hypothesis, the Aspidorhynchiformes, the Pachycormiformes, and the Middle Triassic fish Prohalecites porroi stand as stem teleosts. These taxa are more closely related to crown-group teleosts than to their closest extant relatives (e.g., Amia and Lepisosteus).

Two principal types of scales are present in the clade Teleosteomorpha. Elasmoid scales of cycloid type are the 


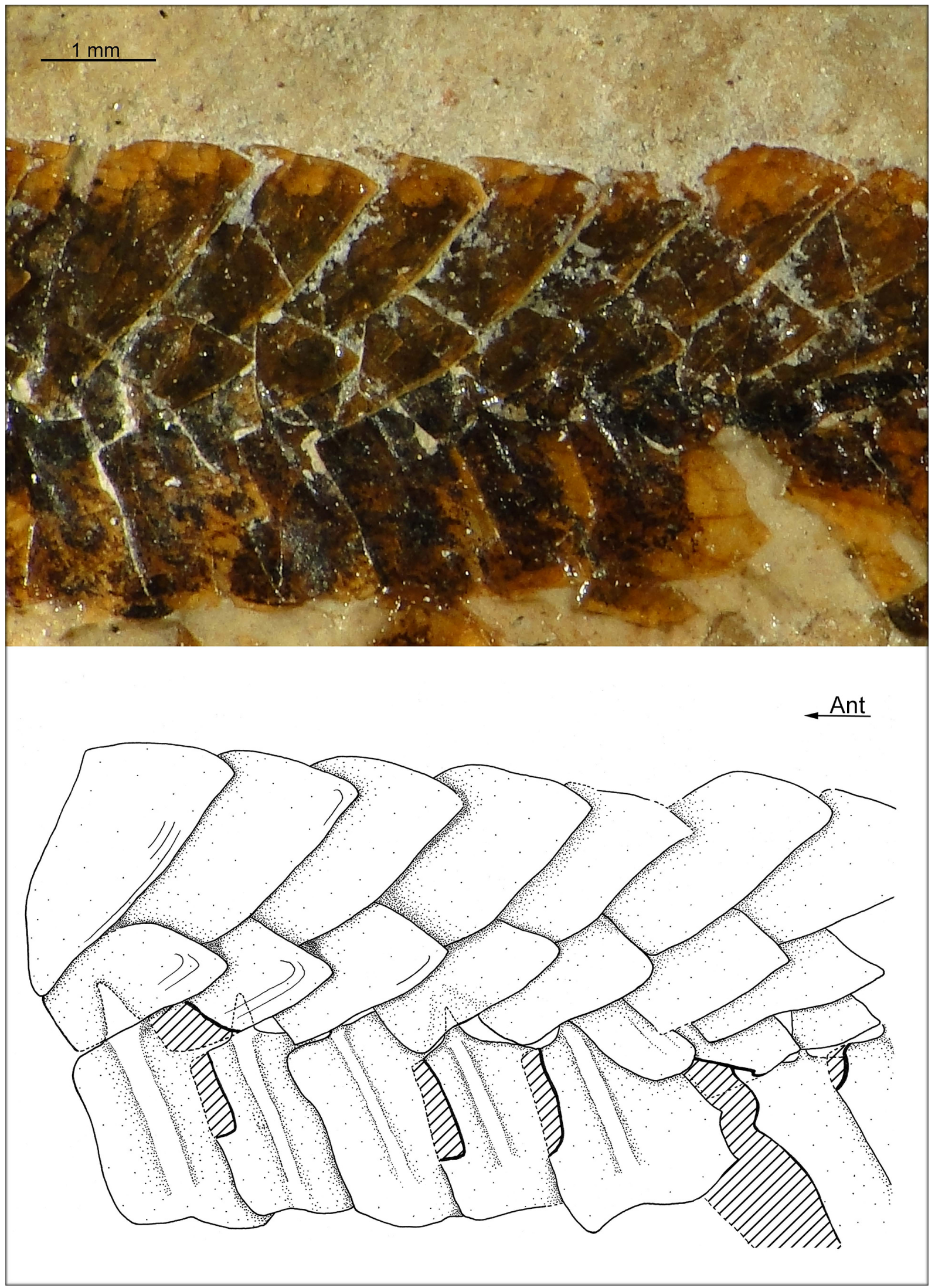

Figure 10. Postcranial region of Teleosteomorpha n. sp. 1 (MIC-V701a). Detail in photograph and drawing of uppermost scale row in lateral view. It shows the second row also, as well as the first row scale from the left side of the specimen; ant, anteriad. 


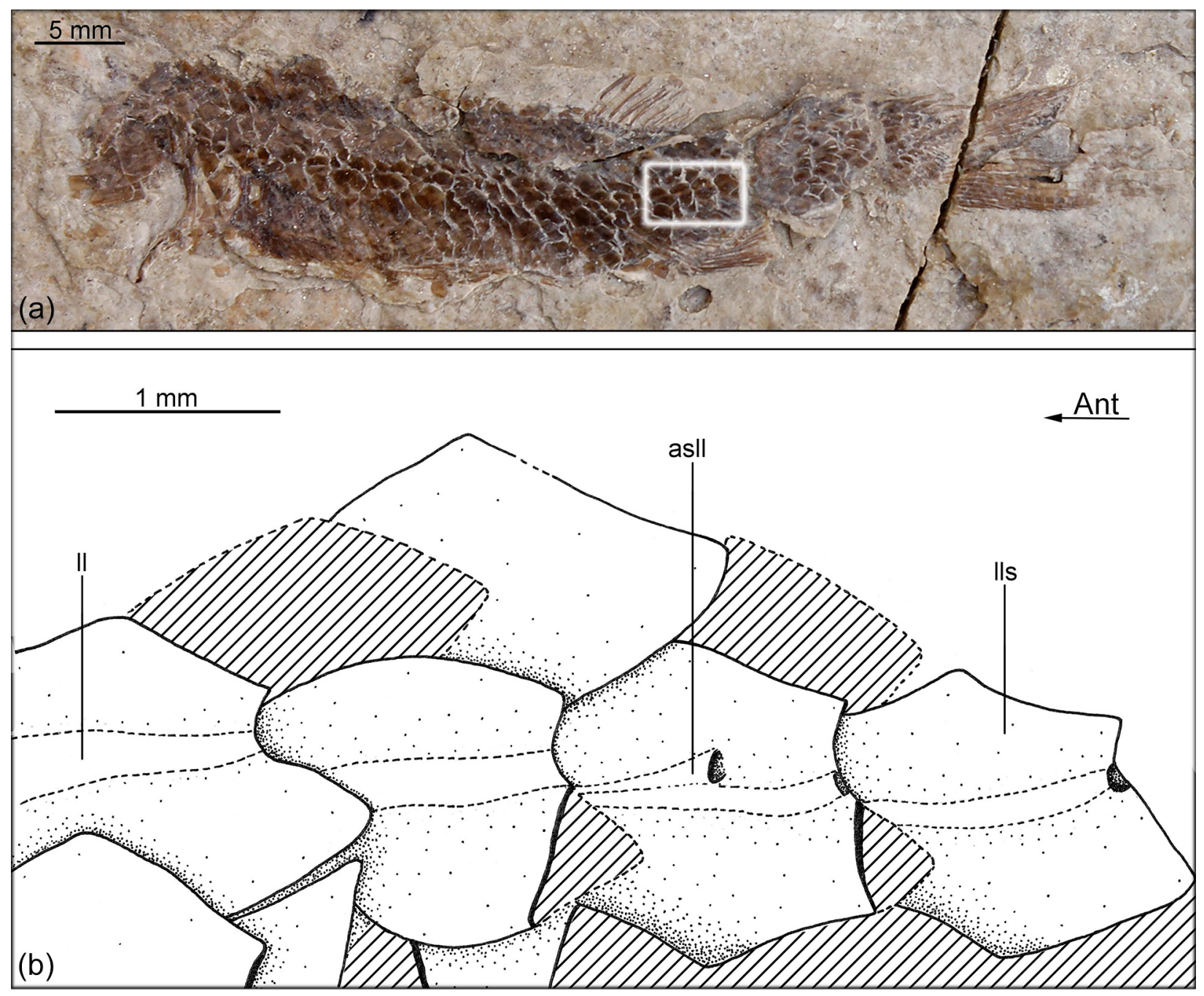

Figure 11. Scales of Teleosteomorpha n. sp. 1. (a) Specimen MIC-V46a. (b) Detail of camera lucida drawing of scales carrying the main lateral line; ant, anteriad; asll, branch from lateral line with opening at surface; 11, main lateral line with opening at posterior margin; 1ls, lateral line scales.

most common. These are restricted to most Teleostei from Leptolepis corhyphaenoides and all more derived ones (Schultze, 1966, 2015; Meunier and Brito, 2004; Arratia and Schultze, 2007; Arratia, 2015). Ganoid scales of lepisosteoide type are present among most basal forms, for example, in members of the family Aspidorhynchidae (Schultze, 1966; Brito, 1997; Brito and Meunier, 2000), in the teleost family Pholidophoridae (Nybelin, 1966; Arratia, 2013, 2015), in Catervariolus hornemani (Taverne, 2011), in species of Siemensichthys (Arratia, 2000), and in Dorsetichthys bechei (Nybelin, 1966; Arratia, 2013). Amioid-type scales are also present among teleosts, but only in species of Eurycormus (Schultze, 1966, 2015; Arratia and Schultze, 2007; Schultze and Arratia, 2015).

Scales of Teleosteomorpha n. sp. 1 from the La Cantera Formation are of the lepisosteoid type with multiple ganoine layers, canaliculi of Williamson (Schultze, 1966,
2015; Sire et al., 2009) in the basal bony layer, and no dentine. The surface of the flank scales is smooth, and microscopically it is bare of tubercles or denticles. This condition is shared with certain teleosts, such as Pholidophorus latiusculus and Pholidoctenus serianus (Arratia, 2013). Contrarily, aspidorhynchids in general present flank scales with macroscopic ganoine ridges and microscopic ornamentations of ganoine tubercles. The genus Aspidorhynchus is the exception, having scales devoid of ganoine (Schultze, 1966; Brito, 1997; Brito and Meunier, 2000; Bartholami, 2004; Gouiric-Cavalli, 2015; Schultze and Arratia, 2015). Pachycormiformes have generally tiny flank scales with very thin ganoine, which may even be missing (Schultze, 1966; Arratia and Schultze, 2013; Gouiric-Cavalli and Cione, 2015). Body scales are absent in the Triassic teleosteomorph Prohalecites porroi (Tintori, 1990). 


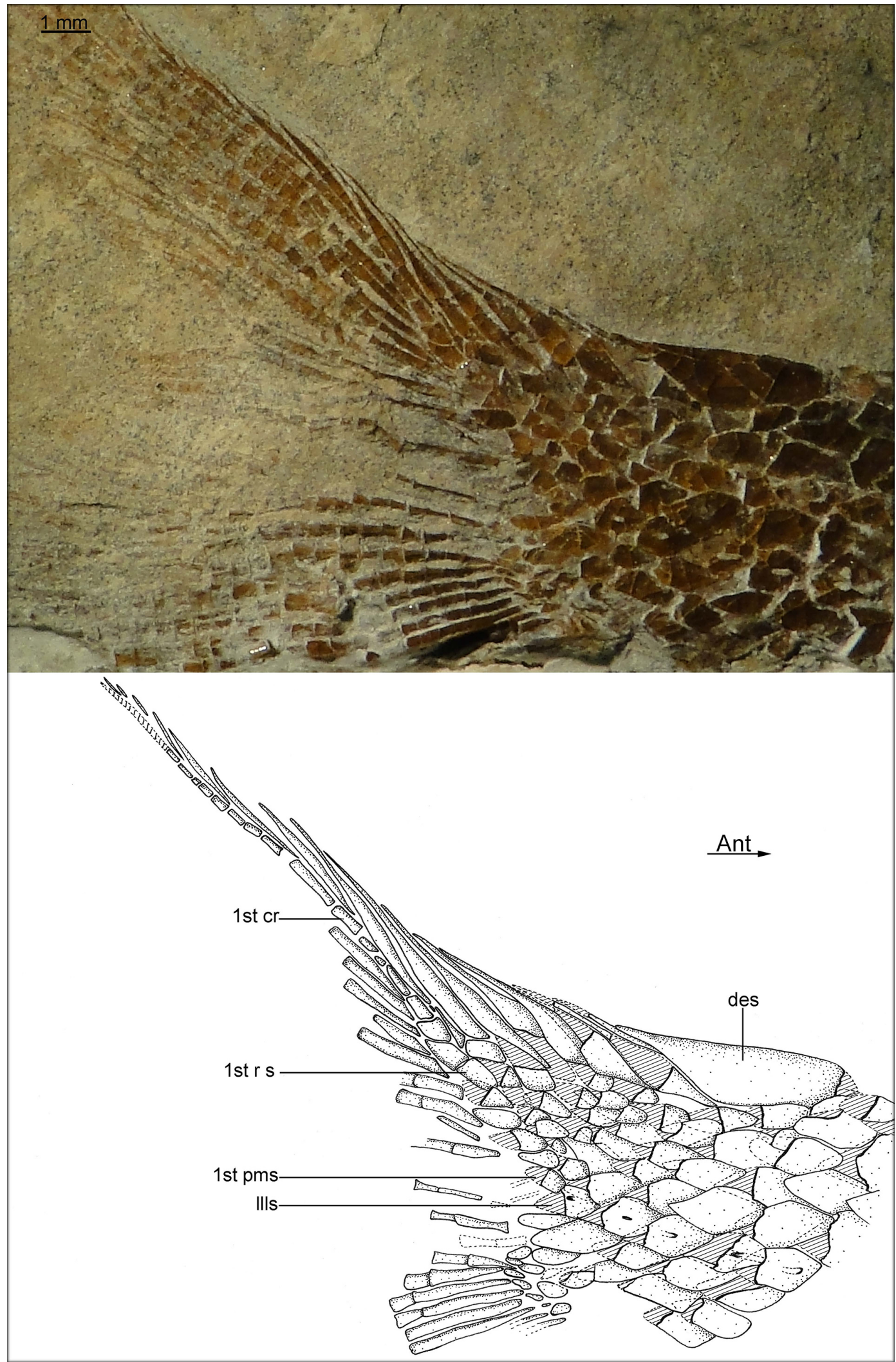

Figure 12. Picture and camera lucida drawing of caudal fin squamation of Teleosteomorpha n. sp. 1 (MIC V523). Dorsal lobe shows the base of the first principal ray covered by scales. Note the dorsal scute preceding caudal fin; ant, anteriad; des, dorsal caudal scute; 1lls, last lateral line scale; 1st cr, first caudal ray; 1st r s, first ray scales; 1st pms, first posterior margin scale. 


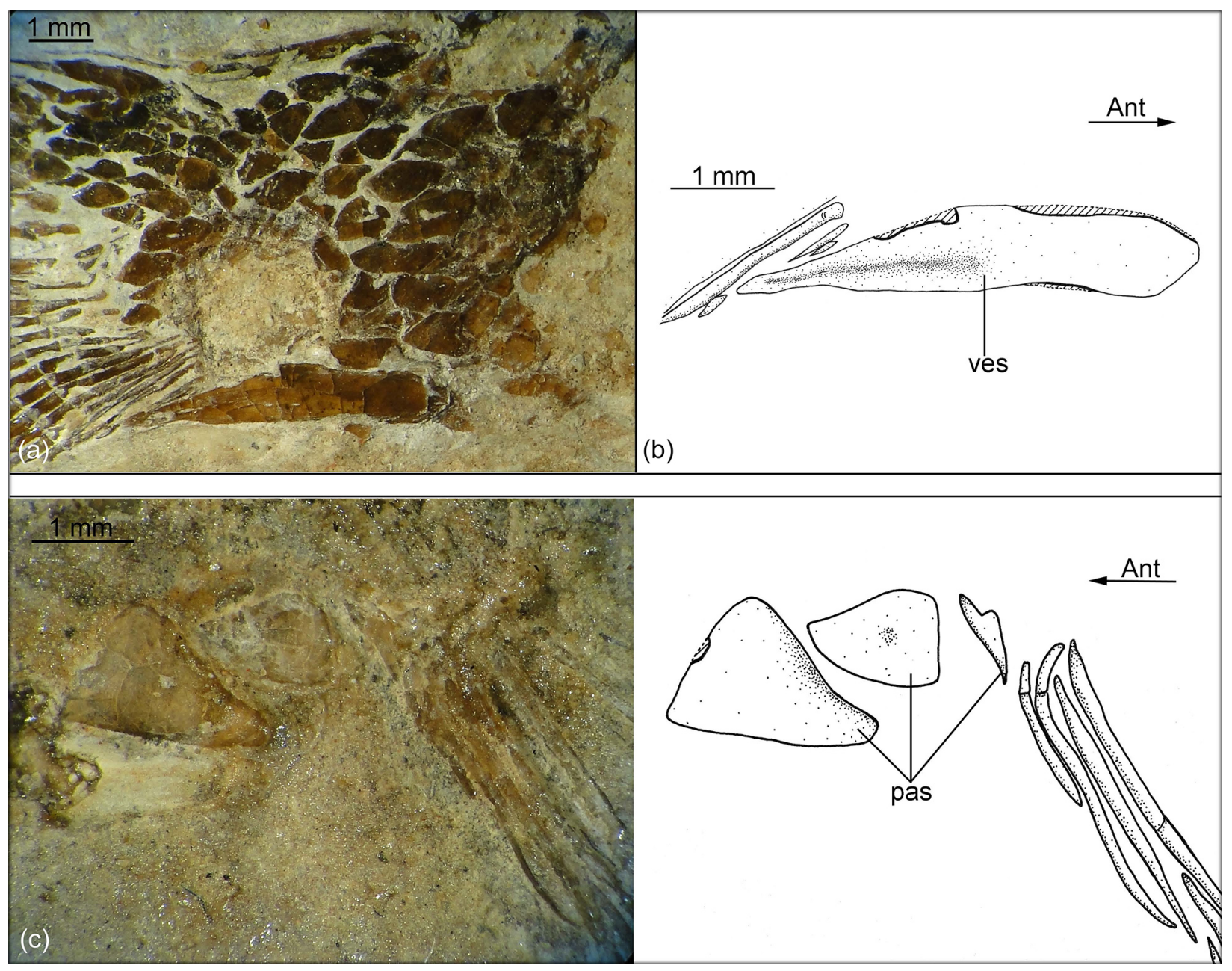

Figure 13. Scutes of Teleosteomorpha n. sp. 1. (a) Ventral scute preceding caudal fin in specimen MIC-V662. (b) Camera lucida drawing of scute in detail. (c) Pre-anal scutes in specimen MIC-V519a; ant, anteriad; pas, preanal scutes; ves, ventral caudal scute.
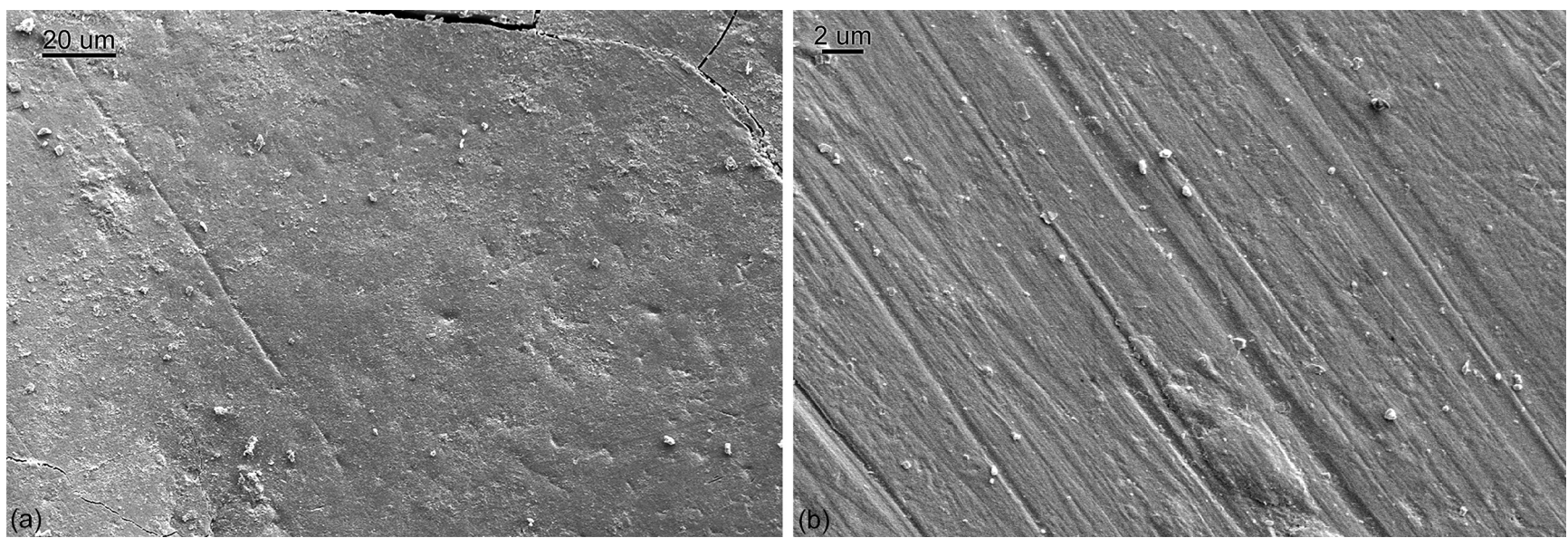

Figure 14. (a) SEM photograph of flank scale of Teleosteomorpha n. sp. 1 (sample "T-5.5"). (b) SEM photograph of flank scale of Teleosteomorpha n. sp. 1 (MIC-V706). 
76 P. G. Giordano et al.: Scale morphology and specialized dorsal scales of a new teleosteomorph fish from the Aptian

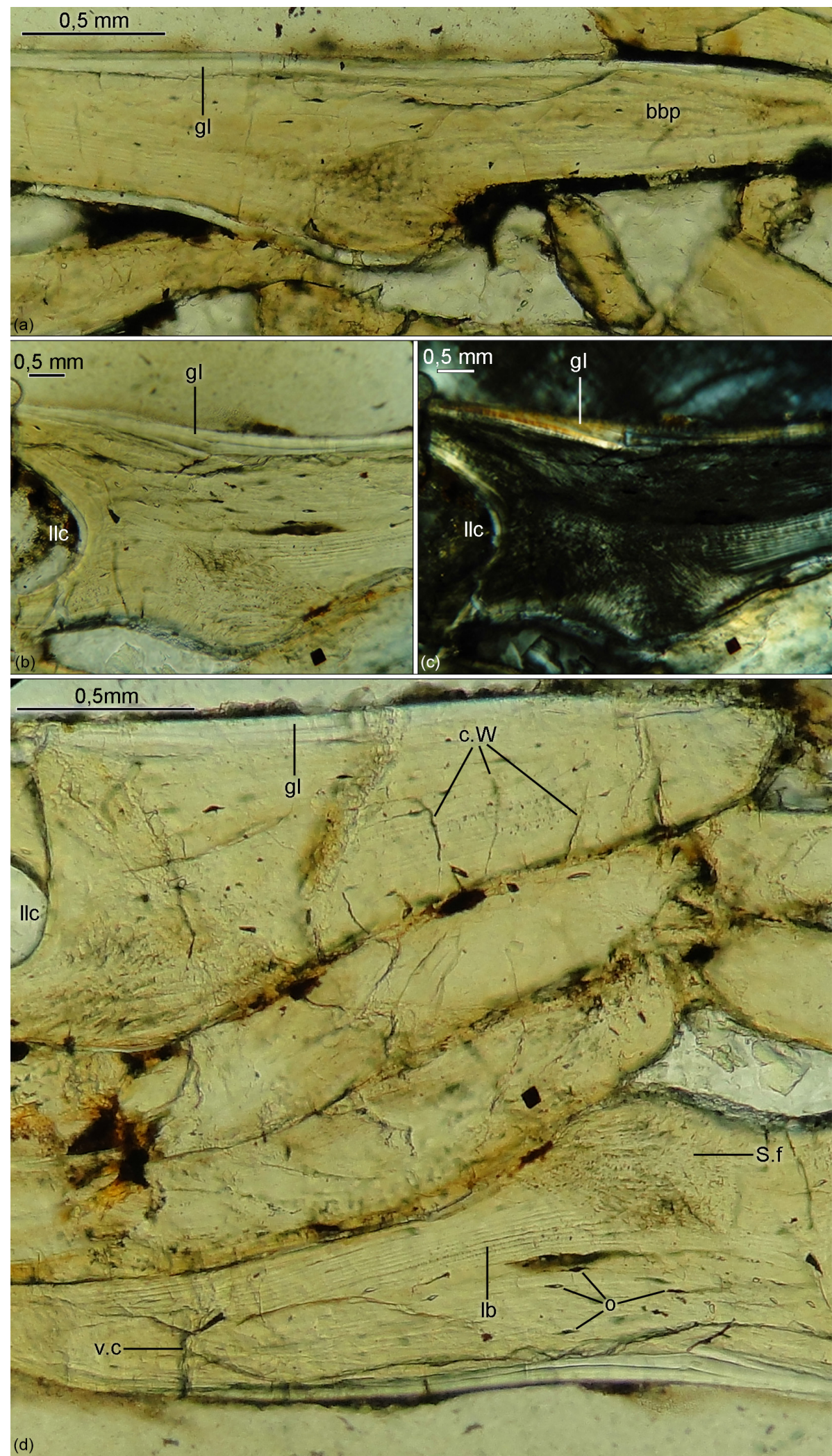

Figure 15. Histological slides of Teleosteomorpha n. sp. 1 (specimen MIC-V523) observed under petrographic microscope. (a) Lepisosteoidscale type. (b) Multiple ganoine layers under normal light. (c) Multiple ganoine layers under polarized light. (d) Ganoine and basal bony plate with all the lepisosteoid features; bbp, basal bony plate; c.W, canaliculi of Williamson; gl, ganoine layers; lb, laminar bone; llc, lateral line canal; o, lacunae (osteocyte spaces); sv.c, vascular canal; S.f, Sharpey's fiber. 
The presence of ganoid scales with peg-and-socket articulation is also a common feature of holostean neopterygians, such as semionotiforms, lepisosteiforms, and macrosemiiforms (Schultze, 1966, 1996, 2015). Ganoid scales of Teleosteomorpha n. sp. 1 of the La Cantera Formation present a well-developed dorsal peg, but they lack an anterodorsal process. The same pattern occurs, for example, in the Macrosemiiformes (e.g., Macrosemius, Propterus, and Legnonotus; Schultze, 1966; Vullo et al., 2009); however, this pattern differs from lepisosteiforms and most semionotiforms (e.g., Cavin et al., 2009; López-Arbarello, 2012; Gibson, 2013), which possess anterodorsal or anteroventral processes. Stem teleosts and a few more advanced ones with ganoid scales also present a peg for articulation in a dorsal position (e.g., Vinctifer comptoni, Jonoichthys challwa, Pholidophorus latiusculus, Knerichthys bronni, Pholidoctenus serianus, Catervariollus hornemani, Siemensichthys macrocephalus, and Dorsetichthys bechei; Schultze, 1966; Brito, 1997; Arratia, 2000, 2013; Taverne, 2011; Gouiric-Cavalli, 2015).

Teleosteomorpha n. sp. 1 presents deeper than long flank scales in their preanal region, as in other Teleosteomorpha with ganoid scales (see Schultze, 1966; Brito, 1997; Brito and Ebert, 2009; Bartholomai, 2004; Arratia, 2000, 2013; Gouiric-Cavalli, 2015). Even though most of the scales studied have straight margins, some have a sinuous posterior margin on the same specimen. In this sense, these scales resemble the scales of some species of the Triassic family Pholidophoridae (Zambelli, 1977; Arratia, 2013). Unique to the fishes from the La Cantera Formation is the undulating ventral margin of the scales (Fig. 3).

The thick, round scales in the ventral margin of the preanal region are ganoid scales and not elasmoid scales, in contrast to the round amioid scales in the anteroventral part of the body of Macrosemiiformes. There are amioid scales in the gular region of some species of macrosemiiforms and, furthermore, there are ganoid scales on the flanks of the same individual (e.g., Macrosemius rostratus, Propterus microstomus, and Notagogus denticulatus; Schultze, 1966; Bartram, 1977; Arratia and Schultze, 2012).

The most dorsal scales of the flank are unique to Teleosteomorpha n. sp. 1 from the La Cantera Formation in being paired structures. Most basal neopterygians have a row of unpaired, bilaterally symmetrical ridge scales in the dorsal midline. For example, these dorsal ridge scales are characteristically elongated into a spine in the family Semionotidae (Olsen and McCune, 1991; López-Arbarello, 2012; Gibson, 2013). Paired scales like those present in Teleosteomorpha n. sp. 1 from the La Cantera Formation have not been reported in any other neopterygian. Indeed, this structure could be considered an autapomorphic character of this South American species.

Ganoine-covered scutes around the anus are not known among stem-group teleosts such as pachycormiforms, aspidorhynchiforms, Prohalecites, and more derived teleosts including Pholidophoridae and other related groups. However, these structures are common among holosteans, such as Semionotiformes, Lepisosteiformes (Bürgin, 2004; Lombardo and Tintori, 2008; Grande, 2010; Cavin et al., 2013), and Macrosemiiformes (Schultze, 1966; Bartram, 1977; Bravi, 1994; González-Rodríguez and Reynoso, 2004; González-Rodríguez et al., 2004; Arratia and Schultze, 2012). In this character, Teleosteomorpha n. sp. 1 from the La Cantera Formation resembles non-teleosteomorph neopterygians.

Ganoine-covered scutes preceding the caudal fin are known within Halecomorpha in general, for example Watsonulus eugnathoides, Ophiopsiella attenuata (= Ophiopsis attenuata), Cipactlichthys scutatus, and Teoichthys brevipina (Grande and Bemis, 1998; Arratia, 2008; Brito and Alvarado-Ortega, 2013; Machado et al., 2013; Lane and Ebert, 2015). These scutes occur in numbers of two to four and generally on both dorsal and ventral margins of the caudal fin. There are also some examples of halecomorphs with a unique dorsal and ventral scute associated with the caudal fin, such as Ophiopsis muensteri (=Furo muensteri), Ophiopsiella procera (=Ophiopsis procera), "Furo" longiserratus, and Eurypoma grande (Schultze, 1966; Arratia and Schultze, 2007; Arratia, 2008; Lane and Ebert, 2012, 2015). In stem-group teleosts and most derived teleosts, it is more common to find one scute associated with the dorsal, ventral, or both margins of the caudal fin. Such scutes in Teleosteomorpha are proportionally much larger than those found in Halecomorpha. Some examples among Teleosteomorpha are the Triassic fish Prohalecites porroi (Tintori, 1990; Arratia and Tintori, 1999), the Cretaceous species herein studied, and aspidorhynchids and pachycormids, with certain species even presenting more than one scute (Arratia and Lambers, 1996; Arratia, 2008; Arratia and Schultze, 2013). Other examples of the presence of caudal scutes among Teleostei at basal nodes are some species of the family Pholidophoridae (e.g., Pholidophorus gervasuttii, Knerichthys bronni, and Parapholidophorus nybelini), the Jurassic fish Dorsetichthys bechei, members of the Siemensichthys group, and Catervariolus hornemani (Arratia, 2000, 2013; Arratia and Schultze, 2007; Taverne, 2011). The caudal fin of these fishes is proceeded by a prominent epaxial scute and a large hypaxial scute - that is, large in comparison to the size of dorsal or ventral basal fulcra. The scutes are covered by ganoine in all these groups. As a rule, the dorsal caudal scute is larger than the ventral one (Arratia, 2008). In contrast, Teleosteomorpha n. sp. 1 from the La Cantera Formation presents both scutes of almost the same size.

Rhombic, modified ganoid scales covering parts of the bases of the upper epaxial caudal rays were defined as urodermals by Patterson (1968) and Arratia and Schultze (1992). The base of the uppermost caudal principal fin ray in specimens of Teleosteomorpha n. sp. 1 from the La Cantera Formation is covered by a row of scales that cannot be considered as urodermal-like elements. Urodermals have 
been described among teleosteomorphs for Prohalecites porroi (Tintori, 1990; Arratia and Tintori, 1999) and certain Pachycormiformes, for example Euthynotus and Sauropsis (Arratia and Lambers, 1996; Arratia and Schultze, 2013), but not for Aspidorhynchiformes. The presence of urodermals is also shared with other groups of Neopterygii, such as certain species of Macrosemiiformes, Lepisosteiformes, and Semionotiformes (Bartram, 1977; Arratia, 2008; LópezArbarello, 2012).

The analysis of the morphological diversity of scales within Neopterygii could provide a set of characters to be used for interspecific differentiation and to show patterns of separation at higher taxonomic levels.

\section{Conclusions}

As in most other basal neopterygians, the fishes described herein show ganoid scales of the lepisosteoid type. The scales of Teleosteomorpha n. sp. 1 from the La Cantera Formation share many common features with other teleosteomorphs in their shape and arrangement. One of the most significant characters is the presence of a prominent scute preceding the dorsal margin of the caudal fin. Unique to the fishes studied here are deep paired dorsal scales with rounded dorsal margins and the lack of median dorsal ridge scales. Among features that Teleosteomorpha n. sp. 1 shares with holosteans are ganoine-covered scutes related to the anal fin.

Author contributions. P. G. Giordano and G. A. initiated and designed the manuscript. P. G. Giordano made the description of the scales and wrote the manuscript with the collaboration of G. Arratia and H.-P. Schultze. Careful corrections of content, as well as language and figures, were made by G. Arratia and H.-P. Schultze Illustrations were made by the first author.

Acknowledgements. The senior author would like to thank Andrea Arcucci (UNSL) and Laura Codorniú (CONICET-UNSL) for encouraging the publication of the present manuscript. The authors thank William E. Bemis (Cornell University) and an anomymous reviewer for their useful comments. We thank Mercedes Prámparo (CONICET-Mendoza) and Gabriela Castillo-Elías (UNSL) for their help with the geological background, professors and students of the paleontological program at UNSL, and all volunteers that provided fieldwork assistance to collect fishes from 2008 to the present. We are grateful to Esteban Crespo (CONICET-UNSL) for his help and assistance with SEM imagery, Federico Gianechini (CONICET-UNSL) for his help with photographs and figures, Daniel Codega (UNSL) for the preparation of petrographic sections, and Ignacio Cerda (CONICET-UNRN) for providing literature. Alejandra Mazzoni (Museo de Paleontología, UNC) and Alberto Cione (CONICET-Museo de La Plata, UNLP) kindly allowed us to study material from the La Cantera Formation held in their institutions. Terry J. Meehan (Rockhurst University, KC, MI) revised the English style of the manuscript. Funding was provided by project PROICO p-3-2-0114 from the Secretaría de Ciencia y Técnica, UNSL, and CONICET (Argentina). Part of this research was conducted at the Biodiversity Institute, University of Kansas, throughout two visits by the senior author.

Edited by: F. Witzmann

Reviewed by: W. Bemis and one anonymous referee

\section{References}

Arcucci, A. B., Puebla, G., Codorniú, L., Giordano, P. G., and Prámparo, M.: A lacustrine biotic assemblage in the Early Cretaceous of central Argentina: La Cantera Formation, in: Proc. Univ. Autón. Madrid, 10th Internat. Symp. Mesozoic Terrestrial Ecosyst. Biota, 16-18 September 2009, Teruel, Spain, 111-112, 2009.

Arcucci, A. B., Prámparo, M. B., Codorniú, L., Giordano, P. G., Castillo-Elías, G., Puebla, G. G., Mego, N., Gómez, M., and Bustos Escalona, E.: Biotic assemblages from Lower Cretaceous lacustrine systems, San Luis Basin, Central-western Argentina, Bol. Geol. Miner., 126, 109-128, 2015.

Arratia, G.: New teleostean fishes from the Jurassic of southern Germany and the systematic problems concerning the "pholidophoriforms", Paläontol. Z., 74, 113-143, 2000.

Arratia, G.: The sister-group of Teleostei: consensus and disagreements, J. Vertebr. Paleontol., 21, 767-773, 2001.

Arratia, G.: Mesozoic halecostomes and early radiation of teleosts, in: Mesozoic Fishes 3: Systematics, Paleoenvironments and Biodiversity, edited by: Arratia, G. and Tintori, A., Verlag Dr. Friedrich Pfeil, München, 279-315, 2004.

Arratia, G.: Actinopterygian postcranial skeleton with special reference to the diversity of fin ray elements, and the problem of identifying homologies, in: Mesozoic Fishes 4: Homology and Phylogeny, edited by: Arratia, G., Schultze, H.-P., and Wilson, M. V. H., Verlag Dr. F. Pfeil, München, 49-101, 2008.

Arratia, G.: Morphology, taxonomy, and phylogeny of Triassic pholidophorid fishes (Actinopterygii, Teleostei), J. Vertebr. Paleontol. 33, 1-138, 2013.

Arratia, G.: Complexities of early Teleostei and the evolution of particular morphological structures through time, Copeia, 4, 9991025, 2015.

Arratia, G. and Cione, A. L.: The record of fossil fishes of Southern South America, in: The vertebrate fossil record of Southern South America, edited by: Arratia, G., Geowiss Abh., München, Germany, 30, 9-72, 1996.

Arratia, G. and Lambers, P.: The caudal skeleton of pachycormiforms: Parallel evolution?, in: Mesozoic Fishes: Systematics and Paleoecology, edited by: Arratia, G. and Viohl, G., Verlag Dr. F. Pfeil, München, 191-218, 1996.

Arratia, G. and Schultze, H.-P.: Reevaluation of the caudal skeleton of certain actinopterygian fishes: III. Salmonidae, J. Morphol., 214, 187-249, 1992.

Arratia, G. and Schultze, H.-P.: Eurycormus - Eurypoma, two Jurassic actinopterygian genera with mixed identity, Foss. Rec., 10, 17-37, 2007.

Arratia, G. and Schultze, H.-P.: The macrosemiiform fish companion of the Late Jurassic theropod Juravenator from Schamhaupten, Bavaria, Germany, Foss. Rec., 15, 5-25, 2012. 
Arratia, G. and Schultze, H.-P.: Outstanding features of a new Late Jurassic pachycormiform-fish from the Kimmeridgian of Brunn, Germany, and comments on current understanding of pachycormiforms, in: Mesozoic Fishes 5: Global Diversity and Evolution, edited by: Arratia, G., Schultze, H.-P., and Wilson, M., Verlag Dr. F. Pfeil, München, 87-120, 2013.

Arratia, G. and Tintori, A.: The caudal skeleton in the Triassic actinopterygian Prohalecites and its phylogenetic position, in: Mesozoic Fishes 2: Systematics and Fossil Record, edited by: Arratia, G. and Schultze, H.-P., Verlag Dr. F. Pfeil, München, 121-142, 1999.

Bartholomai, A.: The large aspidorhynchid fish, Richmondichthys sweeti (Etheridge JNR and Smith Woodward, 1891) from Albian marine deposits of Queensland, Australia, Mem. Queensland Mus., 49, 521-536, 2004.

Bartram, A. W. H.: The Macrosemiidae, a Mesozoic family of holostean fishes, Bull. Brit. Mus. Natur. Hist. (Geol.), 29, 137234, 1977.

Berg, L. S.: A classification of fish-like vertebrates, Bull. Academ. Sci. URSS, Cl Sci Math. Natur. Ser. Biol., 4, 1277-1280, 1937.

Bravi, S.: New observations on the Lower Cretaceous fish Notagogus pentlandi Agassiz (Actinopterygii, Halecostomi, Macrosemiidae), Boll. Soc. Paleontol. I, 33, 57-70, 1994.

Brito, P. M.: Révision des Aspidorhynchidae (Pisces Actinopterygii) du Mésozoïque: ostéologie, relations phylogénétiques, données environnementales et biogéographiques, Geodiversitas, 19, 681-772, 1997.

Brito, P. M. and Alvarado-Ortega, J.: Cipactlichthys scutatus, gen. nov., sp. nov. a new halecomorph (Neopterygii, Holostei) from the Lower Cretaceous Tlayúa Formation of Mexico, PLoS ONE, 8, 1-14, e73551, doi:10.1371/journal.pone.0073551, 2013.

Brito, P. M. and Ebert, M.: A new aspidorhynchid fish (Teleostei: Aspidorhynchiformes) from the Upper Jurassic of Ettling, Solnhofen, Bavaria, Germany, Syst. Palaeontol. (Vert. Palaeontol.), 8, 395-402, 2009.

Brito, P. M. and Meunier, F. J.: The morphology and histology of the scales of Aspidorhynchidae (Actinopterygii, Halecostomi), Geobios, 33, 105-111, 2000.

Bürgin, T.: Eosemionotus ceresiensis sp. nov., a new semionotiform fish (Actinopterygii, Halecostomi) from Middle Triassic of Monte San Giorgio (Southern Switzerland), in: Mesozoic Fishes 3: Systematics, Paleoenvironments and Biodiversity, edited by: Arratia, G. and Tintori, A., Verlag Dr. F. Pfeil, München, 239251, 2004.

Castillo-Elías, G.: Cranial osteology of Chondrostean fishes from La Cantera Formation, Upper Aptian, San Luis, Argentina, in: Ameghiniana, IV Congr. Latinoamer. Paleontol Vert., 2124 September 2011, San Juan, Argentina, 48, 228, 2011.

Castillo-Elías, G., Giordano, P. G., Gómez, M. A., and Janello, J. M.: Estudio tafonómico preliminar del sistema lacustre de La Formación La Cantera, Cretácico Inferior, San Luis, in: Ameghiniana, Reun. De Comunic. Asoc. Paleontol. Argentina, 2123 November 2012, Río Negro, Argentina, 49, 140, 2012.

Cavin, L., Deesri, U., and Suteethorn, V.: The Jurassic and Cretaceous bony fish record (Actinopterygii, Dipnoi) from Thailand, in: Late Palaeozoic and Mesozoic Continental Ecosystems in SE Asia, edited by: Buffetaut, E., Cuny, G., Le Loeuff, J., and Suteethorn, V., Geol. Soc. London, 125-139, 2009.
Cavin, L., Deesri, U., and Suteethorn, V.: Osteology and relationships of Thaiichthys nov. gen.: a Ginglymodi from the Late Jurassic - Early Cretaceous of Thailand, Palaeontology, 56, 183-208, 2013.

Criado-Roque, P., Mombrú, C., and Moreno, J.: Sedimentitas mesozoicas, in: Relatorio VIII Congr. Geol. Argentino, Geología y Recursos Naturales de la provincia de San Luis, VIII Congr. Geol. Argentino, 20-26 September 1981, San Luis, Argentina, 79-96, 1981.

Flores, M.: El Bolsón de las Salinas en la Provincia de San Luis, J. Geol. Argentinas, I, 311-327, 1969.

Gayet, M. and Meunier, F. J.: Apport de l'étude de l'ornamentation microscopique de la ganoïne dans la détermination de l'appartenance générique et/ou spécifique des écailles isolées, C. R. Acad. Sci. Paris II, 303, 1259-1262, 1986.

Gibson, S.: A new hump-backed ginglymodian fish (Neopterygii, Semionotiformes) from the Upper Triassic Chinle Formation of Southeastern Utah, J. Vertebr. Paleontol., 33, 1037-1050, 2013.

Giordano, P. G.: Implicancias evolutivas de supuesto peces "folidoforiformes" (Actinopterygii) de la formación La Cantera (Cretácico Inferior), San Luis, Argentina, Unpubl. PhD Thesis, Fac. Cienc. Natur. Museo, Univ. Nac. La Plata, Buenos Aires, Argentina, 259 pp., 2015.

Giordano, P. G. and Arratia, G.: Ganoid scales of "Pholidophoriforms" (Actinopterygii) from La Cantera Formation, Lower Cretaceous, San Luis, Argentina, in: Ameghiniana, IV Congr. Latinoamer. Paleontol. Vertebr., 21-24 September 2011, San Juan, Argentina, 48, 232-233, 2011.

Giordano, P. G. and Arratia, G.: Los peces ganoideos de la Formación La Cantera (Aptiano), San Luis, Argentina ?por qué no son "Pholidophoriformes"?, in: Ameghiniana, J. Argentinas Paleontol. Vert., 22-24 May 2013, La Rioja, Argentina, 50, 19, 2013.

González-Rodríguez, K. and Reynoso, V.-H.: A new Notagogus (Macrosemiidae, Halecostome) species from the Albian Tlayúa Quarry, Central México, in: Mesozoic Fishes 3: Systematics, Paleoenvironment's and Biodiversity, edited by: Arratia, G. and Tintori, A., Verlag Dr. F. Pfeil, München, 265-278, 2004.

González-Rodríguez, K., Applegate, S. P., and EspinosaArrubarrena, L.: A new world macrosemiid (Pisces: NeopterygiiHalecostomi) form the Albian of México, J. Vertebr. Paleontol., 24, 281-289, 2004.

Gouiric-Cavalli, S.: Jonoichthys challwa gen, et sp. nov, a new aspidorhynchiform (Osteichthyes, Neopterygii, Teleosteomorpha) from the marine Upper Jurassic sediments of Argentina, with comments about paleobiogeography of Jurassic aspidorhynchids, C. R. Palevol., 14, 291-304, 2015.

Gouiric-Cavalli, S. and Cione A. L.: Notodectes is the first endemic pachycormiform genus (Osteichthyes, Actinopterygii, Pachycormiformes) in the Southern Hemisphere, J. Vertebr. Paleontol., 35, e933738, doi:10.1080/02724634.2014.933738, 2015.

Grande, L.: An empirical synthetic pattern study of gars (Lepisosteiformes) and closest related species, based mostly on skeletal anatomy. The resurrection of Holostei, Amer. Soc. Ichthyol. Herpetol. Spec. Publ. 6, Suppl. Iss. Copeia, 10, 1-871, 2010.

Grande, L. and Bemis, W. E.: A comprehensive phylogenetic study of amiid fishes (Amiidae) based on comparative skeletal anatomy. An empirical search for interconnected patterns of natural history, Soc. Vertebr. Paleontol., Mem 4, J. Vertebr. Paleontol., 18, 1-690, 1998. 
Lane, J. A. and Ebert, M.: Revision of Furo muensteri (Halecomorpha, Ophiopsidae) from the Upper Jurassic of Western Europe, with comments on the genus, J. Vertebr. Paleontol., 32, 799-819, 2012.

Lane, J. A. and Ebert, M.: A taxonomic reassessment of Ophiopsis (Halecomorpha, Ionoscopiformes), with a revision of Upper Jurassic species from Solnhofen Archipelago, and a new genus of Ophiopsidae, J. Vertebr. Paleontol., 35, e883238, doi:10.1080/02724634.2014.883238, 2015.

Lombardo, C. and Tintori, A.: A new semionotid fish (Actinopterygii) from the Upper Triassic of northern Italy, in: Mesozoic Fishes - Homology and Phylogeny, edited by: Arratia, G., Schultze, H.-P., and Wilson, M., Verlag Dr. F. Pfeil, München, 129-142, 2008.

López-Arbarello, A.: The record of Mesozoic fishes from Gondwana (excluding India and Madagascar), in: Mesozoic Fishes 3: Systematics, Paleoenviroments and Biodiversity, edited by: Arratia, G. and Tintori, A., Verlag Dr. F. Pfeil, München, 597624, 2004

López-Arbarello, A.: Phylogenetic Interrelationships of Ginglymodian Fishes (Actinopterygii: Neopterygii), PLoS ONE, 7, 144, e39370, doi:10.1371/journal.pone.0039370, 2012.

López-Arbarrello, A., Codorniú, L., Arcucci, A., and Rivarola, D.: Diversidad ictiológica en la Formación La Cantera (Cretácico Temprano) San Luis, Argentina, in: Ameghiniana, J. Argentinas Paleontol. Vert., 22-24 May 2002, Bahía Blanca, Argentina, 39, 13-14, 2002.

Machado, G. P., Alvarado-Ortega, J., Machado, P. L., and Brito, P. M.: Teoichthys brevipina, sp.nov., a new ophiopsid fish (Halecomorphi, Ionoscopiformes) from the Lower Cretaceous Tlayúa Formation, Central México, J. Vertebr. Paleontol., 33, 482-487, 2013.

Meunier, F. and Brito, P.: Histology and morphology of the scales in some extinct and extant teleosts, Cybium, 28, 225-235, 2004.

Nybelin, V. O.: On certain Triassic and Liassic representatives of the family Pholidophoridae s. str., Bull. Brit. Mus. Natur. Hist. (Geol.), 11, 351-432, 1966.

Olsen, P. and McCune, A.: Morphology of the Semionotus elegans species group from the Early Jurassic part of the Newark supergroup of eastern North America with comments on the family Semionotidae (Neopterygii), J. Vertebr. Paleontol., 11, 269-292, 1991.

Ørvig, T.: Phylogeny of tooth tissues: Evolution of some calcified tissues in early vertebrates, in: Structural and Chemical Organization of Teeth, edited by: Miles, A. E. W., Academic Press, New York, London, 1, 45-110, 1967.

Patterson, C.: The caudal skeleton in Lower Liassic pholidophorid fishes, Bull. Brit. Mus. Natur. Hist. (Geol.), 16, 201-239, 1968.

Petruleviciius, J., Nel, A., and Sallenave, S.: Recent genus Notonecta (Insecta: Heteroptera: Notonectidae) in the Lower Cretaceous of San Luis, Argentina: Palaeoecological implications, Ann. Soc. Entomol. France (N S) Internat. J. Entomol., 46, 1-2, 2010.

Prámparo, M. B.: Palynostratigraphy of the Lower Cretaceous of the San Luis Basin, Argentina. Its place in the Lower Cretaceous flora provinces pattern, N. Jb. Geol. Palaeontol., 181, 255-266, 1990.

Prámparo, M. B.: Lower Cretaceous palynoflora of the La Cantera Formation, San Luis Basin: correlations with other Cretaceous palynofloras of Argentina, Cretaceous Res., 15, 193-203, 1994.
Prámparo M. B.: Microfitoplancton orgánico del Cretácico Inferior de la cuenca de San Luis. Parte I: Scenedesmaceae and Chlorococcaceae, Ameghiniana, Publ. Espec., 6, 39-42, 1999a.

Prámparo, M. B.: Granos de polen de primitivas angiospermas en el Cretácico Inferior de la cuenca de San Luis y su distribución en otras cuencas cretácicas de argentina, in: Bolet. V Simp. Cretáceo Brasil, I Simp. Cretácico América del Sur, 29 August2 September 1999, Sao Paulo, Brazil, 539-523, 1999 b.

Prámparo, M. B.: Non-marine Cretaceous palynomorph biostratigraphy of Argentina: a brief summary, J. Stratigr., 36, 213-228, 2012.

Prámparo, M. B., Quattrocchio, M., Gandolfo, M. A., del C. Zamaloa, M., and Romero, E.: Historia evolutiva de las angiospermas (Cretácico-Paleógeno) en Argentina a través de los registros paleo florísticos, Ameghiniana, 50 aniv, 157-172, 2007.

Puebla, G.: A new angiosperm leaf morphotype from the Early Cretaceous (Late Aptian) of San Luis Basin, Argentina, Ameghiniana, 46, 557-566, 2009.

Puebla, G., Mego, N., and Prámparo, M.: Asociación de Briófitas de la Formación La Cantera, Aptiano Tardio, Cuenca de San Luis, Argentina, Ameghiniana, 49, 217-229, 2012.

Richter, M. and Smith, M.: A microstructural study of the ganoine tissue of selected lower vertebrates, Zool. J. Linn. Soc. London, 114, 173-212, 1995.

Rivarola, D. and Spalletti, L.: Modelo de sedimentación continental para el rift Cretácico de la Argentina central. Ejemplo de la Sierra de Las Quijadas, San Luis, Rev. Asoc. Geol. Argentina, 61, 6380, 2006.

Schultze, H.-P.: Morphologische und histologische Untersuchungen an Schuppen mesozoischer Actinopterygier (Übergang von Ganoid- zu Rundschuppen), N. Jb. Geol. Palaeontol., 126, 232314, 1966.

Schultze, H.-P.: The scales of Mesozoic actinopterygians, in: Mesozoic Fishes: Systematics and Paleoecology, edited by: Arratia, G. and Viohl, G., Verlag Dr. F. Pfeil, München, 83-93, 1996.

Schultze, H.-P.: Scales, enamel, cosmine, ganoine, and early osteichthyans, C. R. Palevol., doi:10.1016/j.crpv.2015.04.001, 2015.

Schultze, H.-P. and Arratia, G.: Knochenfische im weiteren Sinne (Osteichthyes oder Osteognathostomata), in: Solnhofen. Ein Fenster in die Jurazeit, 2, edited by: Arratia, G., Schultze, H.P., Tischlinger, H., and Viohl, G., Verlag Dr. F. Pfeil, München, 360-409, 2015.

Sire, J.-Y. and Meunier, F.: The canaliculi of Williamson in holostean bone (Osteichthyes, Actinopterygii): a structural and ultrastructural study, Acta Zool. Stockholm, 75, 235-247, 1994.

Sire, J.-Y., Donoghue, P., and Vickaryous, M.: Origin and evolution of the integumentary skeleton in non-tetrapod vertebrates, J. Anat., 214, 409-440, 2009.

Taverne, L.: Ostéologie et relations de Catervariolus (Teleostei, "Pholidophoriformes") du Jurassique moyen de Kisangani (Formation de Stanleyville) en République Démocratique du Congo, Bull. Inst. Roy. Sci. Natur. Belg. Sci. Terre., 81, 175-212, 2011.

Tintori, A.: The actinopterygian fish Prohalecites from the Triassic of Northern Italy, Palaeontology, 33, 155-174, 1990. 
P. G. Giordano et al.: Scale morphology and specialized dorsal scales of a new teleosteomorph fish from the Aptian 81

Vullo, R., Cavin, L., and Clochard, V.: An ammonite-fish association from the Kimmeridgian (Upper Jurassic) of La Rochelle, western France, Lethaia, 42, 462-468, 2009.
Zambelli, R.: Note sui Pholidophoriphormes II. Pholidoctenus serianus gen. n. sp. n., Rend. Acad. Naz. Lincei, Part 5, 101-124, 1977. 